\title{
K. K. Yudahin'in Kırgızca-Rusça Sözlüğünde Geçen Seyrek Kullanılan Kelimeler Hakkında Bir Değerlendirme ${ }^{1}$
}

\author{
Meder SALIEV ${ }^{2}$
}

Öz

Bu yazıda K. K. Yudahin tarafından hazırlanan ve Kırgız Türkçesinin söz varlığını incelemede önemli kaynakların biri olan 1985 tarihinde basılmış olan "Kırgızca-Rusça Sözlük" üzerinde durulmuştur. Yazarın, eserin açıllama bölümünde 31 maddelik açıklamanın 29. maddesinde bazı kelimelerin yanına peАко (seyrek) işaretini koyduğu görülmektedir. Ama yazar, bu işareti kullanırken bu işaretlediği kelimelerin niçin ve neye göre seyrek kullanılan kelimeler olduğu üzerine herhangi bir bilgilendirme yapmamıştır. Sözlükte Yudahin tarafindan seyrek olarak işaretlenen kelimelere baktığımızda toplam yüz elli iki tane kelime tespit edilmiştir. Bu kelimeler Arapça, Farsça, Rusça, Çince olmakla birlikte kökeninin Moğolca olabileceği kelimler dışındaki kelimelerin yarısı Türkçe (Kırgızca) kelimelerden oluşmaktadır. Bu makalede tespit ettiğimiz seyrek kelimelerin ne anlam taşıdıkları, kelimenin kökünün neye dayandığı ve kelimenin kökünde nasıl ses olayları meydana geldiği üzerinde durulmuştur. Tespit edilen kelimeler içerisinde Arapça, Farsça ve Rusça kelimelerin Kırgız Türkçesinin ses özelliklerine uygun olarak değiştirildiği görülmektedir. Türkçe (Kırgızca) kelimelerde ise ciddi ses değişikleri görülmemekle birlikte seyrek olarak işaretlenen kelimelerin özelliklerine baktığımızda Kırgız yazı dilinde kullanılmayan kelimelerin çoğu Türkçenin tarihi dönmelerinde yazılmış olan eserlerde, Kırgız Türkçesi dışında diğer Türk lehçelerinde ve az sayıda olsa Kırgız Türkçesinin ağızlarında görülmektedir.

Anahtar Kelimeler: Sözlükte geçen seyrek kullanılan kelimeler, Arapça unsurlar, Farsça unsurlar, Türkçe kelimelerde görülen ses olayları.

\section{Rare Words in Yudakhin's Kyrgyz-Russian Dictionary}

\begin{abstract}
In this article, the "Kyrgyz-Russian Dictionary" prepared by K. K. Yudahin and published in 1985, which is one of the important sources in examining the vocabulary of Kyrgyz Turkish, is emphasized. It is seen that the author put the редко (sparse) sign next to some words in the 29 th article of the 31 -item of explanation. However, while using this sign, the author did not give any information about why and according to which reason the words he marked are infrequently used words. When we look at the words that are signed sparse in the dictionary, it is observed that it consists of totally 150 words. Although these words are Arabic, Persian, Russian and Chinese, half of the words are Turkish (Kyrgyz) words, except for the words whose origin may be Mongolian. In this article, the meaning of the rare words we have identified, what the root of the word is based on and how phonetic events occur in the root of the word are emphasized. Among the detected words, it is considered that Arabic, Persian and Russian words are changed in accordance with the phonetic characteristics of Kyrgyz Turkish (language). In Turkish (Kyrgyz) words, on the other hand, there are no serious sound changes, but when we look at the features of the words that are marked as rarely, most of the words that are not used in the Kyrgyz written language are seen in the works written in the historical period of Turkish, in other Turkish dialects other than Kyrgyz Turkish, and in a small number in the dialects of Kyrgyz Turkish (language).
\end{abstract}

Key Words: Rare Words, Arabic Words, Persian Words, Turkic Words, Phonetics

\section{Atıf İçin / Please Cite As:}

Saliev, M. (2021). K. K. Yudahin'in Kırgızca-Rusça sözlüğünde geçen seyrek kullanılan kelimeler hakkında bir değerlendirme. Manas Sosyal Arastırmalar Dergisi, 10(ÖS), 12-32.

Geliş Tarihi / Received Date: 23.11.2020

Kabul Tarihi / Accepted Date: 22.11.2021

\footnotetext{
1 Bu makale, 26-28 Nisan 2017 tarihinde düzenlenen IV. Uluslararası Türk Dünyası Araştırlmaları Sempozyumu’nda sunulan bildiriden genişletilmiştir.

2 Dr. Öğr. Üyesi - Niğgde Ömer Halisdemir Üniversitesi Fen Edebiyat Fakültesi, medersaliev1985@gmail.com

(D) ORCID: 0000-0001-5800-570X
} 


\section{Giriş}

1925 yılının sonlarında Sovyetler Birliği Bilimler Akademisi’nde Radloff tarafindan hazırlanan "Türk Lehçeleri Lügati Tecrübesi” adlı eserin düzeltilerek ikinci kez basılması için karar alınmıştır. Bu düzeltme işinde Yudahin eserin V. bölümünü oluşturan Kırgızca maddesini ele almıştır (Nuriahmetova, 2015, s. 354).

Bu maddeyi incelerken manaları anlaşılmayan birçok kelime ve tabirlere rastlamıştır. Yudahin, bu gibi anlaşılmayan kelimeleri aydınlatmak için dönemin gazeteleri, ders kitapları, folklor ve edebiyat eserlerini teker teker incelemeye başlamıştır. Bu başvurmuş olduğu kaynaklarla istediği gibi sonuca ulaşamayınca da Kırgızistan'ın her bölgesini dolaşarak derleme yapmıştır. Yazar eserinde 1928'de derleme için Isık-Köl'e gittiğinden bahsetmektedir. Bu bilgiden yola çıarak yazarın 1928 y1lından 1940 yılına kadar eseri hazırlamak için derleme işiyle uğraştığını söyleyebiliriz (Yudahin, 1985a, s. 7). Bu derleme sonucunda fişlemiş olduğu bilgiler Radloffun hazırladığı eserden daha fazlaydı. Bu da Yudahin için ayrı bir sözlük hazırlamasına imkân sağlamıştır.

1923 yılından itibaren Kırgız Türkçesinin yazı dili olarak kullanılmaya başladığından dolayı, bu dönemde Kırgız Türkçesi ile yazılmış eserlerin sayı bakımından az olması Kırgız Türkçesinin zenginliğini gereği gibi yansıtamamıştır. Yudahin, malzeme toplamak üzere edebiyat dışında folklor ve konuşma diline de başvurmak zorunda kalmıştır. Kırgız sözlük malzemesi ilk defa toplandığ1 için Yudahin, bu derlemelerde geçen bütün kelimeleri iki cilt halinde hazırlamış olduğu sözlükte kullanmıştır. Sözlükte geçen kelimeleri toplamada dönemin ileri gelen ağız araştırmacılarından, Türkologlardan da faydalanmıştır (Taymas, 1988, s. v).

Bu makalede 1985 yılında basılmış olan sözlükte Yudahin tarafindan seyrek olarak işaretlenen kelimeler üzerinde durulmuştur. Sözlüğün açıklama bölümünde yazar, 31 maddelik açıklamanın 29. maddesinde редко (seyrek) (Yudahin, 1985, s. 14) diyerek bazı kelimeleri seyrek kullanılan kelimeler olarak işaretlemiştir. Ama yazar, sözlükte bu kelimeleri niçin ve neye göre seyrek kullanılan kelimeler olarak işaret ettiği hakkında açıklama yapmamıştır. Makalenin amacı da bu seyrek kullanılan kelimeleri bir araya getirmek, kelimelerin orijinal şekillerini ortaya koymak, diğer Kırg1z sözlüklerinde kullanılip kullanılmadığını tespit ederek Yudahin’in seyrek kullanılan ibaresine açıklık kazandırmaktır.

\section{K. K. Yudahin'in “Kirgızca-Rusça Sözlük’ünde Geçen Seyrek Kelimeler}

Yudahin'in bu sözlükte seyrek olarak işaretlediği kelimleler 154 tanedir. Bu kelimelerden bazıları Arapça, bazıları Farsça olup bazılarının da kökenleri tespit edilememiştir. Seyrek olarak tespit edilen bazı kelimeler ise Türkçe (Kırgızca) olup gerçekten kullanım sıklığ1 düşük kelimelerdir.

\section{Seyrek Kullanılan Farsça Kelimeler}

İncelediğimiz sözlükte toplam 33 tane Farsça kökenli seyrek kullanılan kelime tespit edilmiştir.

Abaz Far:: ses (Yudahin, 1985a, s.17)< āvāz: Ses, seda: (Devellioğlu, 2008, s. 53).

$\overline{\mathbf{a}}>$ a: Farsça kelimelerdeki uzun ünlüler Kırgız Türkçesinde büyük çoğunlukla kısalmıştır (Kasapoğlu, 2005, s.50). Rusça dişında diğer alıntı kelimelerde kelime başı ve kelime içinde yer alan /v/ ünsüzü Kırg1z Türkçesinde /b/'ye dönüşür. 355).

Amma, amme Far: hepsi (Yudahin, 1985a, s. 55)< heme: cümle, bütün, hep (Devellioğlu, 2008, s.

h-> ø: Alıntı kelimelerde kelime başında bulunan /h-/ sesi Kırgız Türkçesinde genellikle düşer (Kasapoğlu, 2005, s.102). Farsça heme kelimesinin Kırgız Türkçesinde kelime başındaki /h-/ sesinin düştüğü, kelime içinde yer alan /m/ sesinin ise ikizleştiği görülmektedir.

Aram Far: zevk, haz (Yudahin, 1985a, s. 64)< ārām: 1. Durma, eğlenme, dinlenme. 2. Yerleşme, istirahat etme (Devellioğlu, 2008, s. 35).

$\overline{\mathbf{a}}>$ a: Farsça kelimelerdeki uzun ünlüler Kırgız Türkçesinde büyük çoğunlukla kısalmıştır. 
Ariyne $^{3}$ Far: elbette, tabii (Yudahin, 1985a, s. 67).

Azbaray Far: azbaray kuda, Allah için yemin ederim (Yudahin, 1985a, s. 26)< ez (f.e) "dan, den" (Devellioğlu, 2008, s. 245) +berāy: için, maksadıyla (Devellioğlu, 2008, s. 86)> azbaray: için, sebebinden (Taymas, 1988, s. 74).

Barañda Far: kuş (Yudahin, 1985a, s. 109).

p->b-: Farsça kelimelerin başında yer alan /p/ sesi Kırgız Türkçesinde korunmakla birlikte bazı kelimelerde kelime başı /p/ sesi tonlulaşarak /b/'ye dönüştüğü görülür (Kasapoğlu, 2005, s.86). < perende: 1. av kuşu (Devellioğlu, 2008, s. 859).

Berende Far: kuş (Yudahin, 1985a, s. 129)< perende: 2. av kuşu (Devellioğlu, 2008, s. 859).

p->b-: Farsça kelimelerin başında yer alan /p/ sesi Kırgız Türkçesinde korunmakla birlikte bazı kelimelerde kelime başı /p/ sesinin tonlulaşarak /b/'ye dönüştüğü görülür (Kasapoğlu, 2005, s.86). < perende: 2. av kuşu (Devellioğlu, 2008, s. 859).

Berk Far: 1. yaprak (Yudahin, 1985a, s. 130)< berg: yaprak (Devellioğlu, 2008, s. 87).

Eski Türkçede kelime sonunda yer alan /g/ sesi Kırgız Türkçesinde bazı beg > bek, tüg > tük gibi kelimelerde tonsuzlaşarak /k/ ünsüzüne dönüşür (Kasapoğlu, 2005, s. 88). Farsça yaprak anlamına gelen berg kelimesinin de bu kurala uygun olarak Kırgız Türkçesinde berk şeklini almış olduğunu söyleyebiliriz.

Butparas Far: putperest (Yudahin, 1985a, s. 163).

put: bazı ilkel toplumlarda doğaüstü güç ve etkisi olduğuna inanılan canlı veya cansız nesne, tapınacak, senem, fetiş (Türkçe Sözlük, 2011, s. 1954), -perest: “tapan, tapınan, taparcasına seven” manalarılla birleşik kelimeler yapılır (Devellioğlu, 2008, s. 859). Putperest: butperest puta tapan (Türkçe Sözlük, 2011, s. 1954).

Farsça kelimelerin başında yer alan /p/ sesinin Kırgız Türkçesinde korunmakla birlikte bazı kelimelerde kelime başı /p/ sesi tonlulaşarak /b/'ye dönüştüğü görülür (Kasapoğlu, 2005, s. 86). Aynı zamanda Farsçadan giren kelimelerde /x/, /s/ ve /ş/ ünsüzlerinden sonra gelen /t/ ünsüzü telaffuz zorluğundan düşer (Kasapoğlu, 2005, s. 102). Bu kurallara göre putperest> butparas şeklini almıştır.

Cahan. II. caan. Far:: Dünya, yeryüzü (Yudahin, 1985a, s. 240).

-i->-a-: Farsça cihān "dünyā, älem" (Devellioğlu, 2008, s. 141) kelimesinde yer alan /i/ sesi Kırgız Türkçesinde genişleyerek /a/'ya dönüşerek halk ağzında cahan (Arıkoğlu vd., 2017, s. 475) şeklini almıştır. Aynı zamanda Kırgız Türkçesinde iki veya daha fazla heceli alıntı kelimelerde iki ünlü arasında yer alan /h/ ünsüzünün düşmesi ile oluşan uzunluğun sonucunda (Kasapoğlu, 2005, s. 50) caan şeklini aldığ şekli de kullanılmaktadır.

Caran Far: 1. arkadaş (Yudahin, 1985a, s. 233)< yārān: dostlar (Devellioğlu, 2008, s. 1156).

Türkçe kelimelerin başında yer alan /y/ ünsüzünün diş eti- ön damak ünsüzü /c/ sesine dönüşmesi Kırgız Türkçesinde oldukça düzenlidir. Bu kuralı, Farsça yärän kelimesi üzerinde de görmekteyiz. Kelime y-> c- ve $\overline{\mathbf{a}}>\mathbf{a}$ a ses değişimlerine uğrayarak Kırgız Türkçesinde caran şeklini aldığı görülmektedir.

Darçin Far: tarçın (Yudahin, 1985a, s.186) < dārçîn: Tarçın (Devellioğlu, 2008, s. 166).

Alıntı kelimelerde kullanılan uzun ünlüler Kırgız Türkçesinde büyük çoğunlukla kısalmıştır. Bu örnekte de /ā/ ve /î/ uzun ünlülerinin kısaldığı görülmektedir.

Daremet Far: gelir, kazanç (Yudahin, 1985a, s.186)< der-āmed: 1. Gelir. 2. Eli dolu (gelme) (Devellioğlu, 2008, s. 174).

Alıntı kelimelerin sonunda bulunan /d/ sesi Türkçeleștirme eğilimi sonucunda Kırgız Türkçesinde tonsuzlaşarak /t/'ye dönüşür (Kasapoğlu, 2005, s. 87). Diğer yandan Farsça kelimelerde yazıda gösterilmeyen /e/ ünlüsünün /a/'ya dönüşmesi ve /ā/ ünlüsünün de kısalarak /e/ olmasından dolayı derāmed kelimesi daremet şeklini almı̧tır.

\footnotetext{
${ }^{3}$ Kırgız Türkçesindeki ariyne Far: Ârî (Far); evet (Devellioğlu, 2008, s. 38)anlamındaki kelimeden gelmiş olabilir. Kırgız Türkçesinde elbette anlamına gelen âr̂̀ edatının karşıllı̆̆ Türkiye Türkçesinde evet anlamını taşımaktadır. Evet "elbette, muhakkak" (Hacieminoğlu, 1992, s. 240).
} 
Dastar Far:: sarık (Yudahin, 1985a, s. 187)< destār: sarık, tülbent (Devellioğlu, 2008, s. 178).

Faana Far: paana ile aynı, penah (Yudahin, 1985a, s. 328).

Faana< penāh: bir şeyin sığınağı, koruyucusu, dayanağı (Devellioğlu, 2008, s. 857).

Farsça kelimelerin sonunda yer alan /h/ ünsüzü Kırgız Türkçesinde düşerek yanındaki ünlüyü uzatmaktadır. Ancak bu kelimede $/ \mathrm{h} /$ ünsüzünün düşmesine rağmen ünlü uzamamıştır. Birinci hecede yer alan /e/ ünlüsün de /a/'ya dönüştüğü görülmektedir. Kırgız Türkçesindeki kalınlık-incelik uyumu Farsçadan giren kelimelerde de görülmektedir. Bu kelimeler çoğunlukla Türkçe kelimeler gibi düzenli bir kalınlık-incelik uyumu göstermektedir (Kasapoğlu, 2005, s. 62). Farsça kelimelerin başında yer alan /p/ sesi Kırgız Türkçesinde kendini genellikle korumuşken bu örnekte /f/'ye dönüştügü görülmektedir.

Irooşan Far: parlak, 1şıltılı (Yudahin, 1985b, s. 439)< rūşen: 1. Aydın, parlak (Devellioğlu, 2008, s. 899).

Kelime, /r/ ünsüzü ile başladığı için kelimenin başına /1-/ ünlüsü türetildiği görülmektedir. Aynı zamanda Kırgız Türkçesinde Farsçadan girmiş olan kelimelerde ilk hecede yer alan / $\bar{u} /$ kısalarak genişlemektedir.

Kerkana Far:: 1. iş yeri, atölye (Yudahin, 1985b, s. 379)< kār-hāne: 1. İş yeri, iş işlenen yer (Devellioğlu, 2008, s. 490).

Kırgız Türkçesinde bazı alıntı kelimelerde son hecede bulunan /āa ünlüsü kısalır. /k/ ön damak ünsüzünün ve kelime içindeki ince ünlünün etkisi ile incelerek /e/'ye dönüşür (Kasapoğlu, 2005, s.76). Ancak tek heceli olan kêrr kelimesinde ise ilk hecede bulunan $/ \bar{a} /$ ünlüsünün /k/ ünsüzünün etkisi ile inceldiği görülmektedir. Kana kelimesi ise Farsça bāne kelimesinden gelişmiştir.

Koco Far: (bakınız aca): 3. patron, efendi, beyefendi (Yudahin, 1985b, s. 392)< hāce Far: 1. Hoca, efendi, ağa, çelebi, sahip, muallim (Devellioğlu, 2008, s. 305).

Külüstön Far: 1. Gülüstön ile aynıdır, çiçek bahçesi. Balaluu üy- külüstön, balasız üy- körüstön "Cocuklu ev-gül bahçesi, çocuksuz ev- mez̧arlkedr?" (Yudahin, 1985b, s.464)< gül-istān: gülzār (Devellioğlu, 2008, s. 298).

Alıntı kelimelerde ön seste bulunan /g/ sesi Kırgız Türkçesinde genellikle tonsuzlaşarak /k/ ünsüzüne dönüşür. Aynı zamanda Türkçe ve alıntı kelimelerde ilk hecede yer alan /ö/ ve /ü/ ünlülerinden sonra gelen /i/ ünlüsü de yuvarlaklaşır (Kasapoğlu, 2005, s.78). Buna göre gül-istän kelimesinin başında g$>$ k- ve kelime içinde -i- >-ü- sesleri değişmekle birlikte son hecede yer alan /-ā-/ ünlüsü de ilerleyici benzeşmenin sonucunda yuvarlaklaştı̆̆ görülmektedir.

Lep: 2. su kenarı (Yudahin, 1985b, s. 6). Yudahin, sözlükte bu kelimenin kökenini belirtmemiştir. Kelime, "deniz kenarı" anlamında leb-i deryā kelimesinde geçen Farsça leb "dudak" kelimesinden gelmektedir (Devellioğlu, 2008, s. 627).

Mader Far: baba (Yudahin, 1985b, s.10)< māder Far:: anne, ana (Devellioğlu, 2008, s. 560).

Meymankana Far: otel (Yudahin, 1985b, s. 23)< mihmān-hāne: misafirhāne, otel (Devellioğlu, 2008, s. 645).

Farsça mihmān kelimesindeki /h/ ünsüzünün etkisi ile ilk hecedeki /i/ ünlüsü genişleyerek /e/'ye dönüşmüştür (Kasapoğlu, 2005, s.79). Aynı zamanda Arapça ve Farsça kelimelerin içinde yer alan /h/ sürekli ünsüzü /y/ sürekli ünsüzüne dönüşmüştür (Kasapoğlu, 2005, s. 93). Bu ses olayı Kırg1z Türkçesinde $A r$ rahim> 1 rayım, şahid $>$ şeyit, nasihat> nasıyat, Far. bihişt> beyiş, dihkan $>$ dıykan gibi örneklerde de görülmektedir (Kasapoğlu, 2005, s. 94).

Nar: 2. çift hörgüçlü deve (Yudahin, 1985b, s. 53). Yudahin, sözlükte geçen nar kelimesinin kökenini belirtmemiştir. Bu kelimenin birinci anlamını tek hörgüçlü deve şeklinde açıklarken ikinci anlamını ise çift hörgüçlü deve olarak belirterek kelimenin ikinci anlamını seyrek kullanılan kelime olduğunu belirtmiştir.

Nar, Çağdaş Kırgız Türkçesinde tek hörgüçlü deve için kullanılmaktadır (Arıkoğlu vd., 2017, s. 1601). Kelime Farsça ner "1. erkek deve 2. mec. cesur erkek 3. mec. bahadır" (Akdoğan, 1999, s. 603) kelimesinden gelmektedir. 
Niyaz Far: 1. sadaka 2. erdem, fazilet (Yudahin, 1985b, s. 57)< niyāz: 1. yalvarma, yakarma. 2. Dua (Devellioğlu, 2008, s. 842).

Orozgar (orazgar) Far: ev ekonomisi (Yudahin, 1985b, s. 79)< rûzî: 1.gündüze ait, gündüzle ilgili. 2. rızık, azık: nasip, kısmet (Devellioğlu, 2008, s. 899)+ kār: iş, güç, 2. kazanç, temettu' (Devellioğlu, 2008, s. 488). Ev işleri (Yudahin, 1985b, s.78).

/r/ ile başlayan alıntı kelimelerin başına /o/ sesi türemiştir. Aynı zamanda Farsça kelimelerde ilk hecede yer alan / $\overline{\mathrm{u}} /$ ünlüsü kısalarak genişlemiştir ve orta hecede bulunan /î/ ünlüsünün de kısalarak düştüğü görülmektedir. Kelime başında / o-/ türemesi Rus> Orus örneğinde de görülmektedir (Kasapoğlu, 2005, s.80).

Paya Far:: 2. dayanak, payanda (Yudahin, 1985b, s. 109). Farsça pāye "basamak, merdiven basamağı" (Devellioğlu, 2008, s. 1001) kelimesinden gelmektedir.

Perberdiger Far: sağlayıc1 (Allah'in epiteti) (Yudahin, 1985b, s. 109)< perverd-gār Far: besleyici, terbiye edici, rızıklandırıcı: Allah (Devellioğlu, 2008, s. 862).

Kırgız Türkçesinde Farsça kelimelerin başında yer alan /p/ sesi çoğunlukla kendini korumuştur. Aynı zamanda diş-dudak /v/ ünsüzü Kırgız Türkçesinde Rusça kelimeler dışında kelime başında ve içinde bulunmaz. Rusça dışında Arapça ve Farsça kelimelerde bulunan /v/ sesi Kırgız Türkçesinde /b/'ye dönüşmüştür.

Sarbar Far:: yönetici, idareci, elebaşı (Yudahin, 1985b, s. 137)< server: baş, başkan, reis, ulu (Devellioğlu, 2008, s. 944).

Arapça ve Farsça kelimelerde yazılmayan ünlü Kırgız Türkçesinde büyük çoğunlukla /a/ olarak kullanılmaktadır (Kasapoğlu, 2005, s. 74). Buna göre sarbar< server kelimesi üzerinde -e-> -a- ve -v->-bdeğişimlerinin olduğu görülmektedir.

Serbaa Far: değerli (Yudahin, 1985b, s. 145)< ser-behā: baş pahası: diyet, haraç (Devellioğlu, 2008, s. 940), k1ymetli (Taymas, 1988, s. 646).

Farsça ser-behā kelimesinin "1. Baş, kafa. 2. Baş, başkan 3. Tepe, doruk 4. Uç, kenar 5. Nihayet, son" anlamına gelen ser şekli (Devellioğlu, 2008, s. 939) Kırgız Türkçesinde kendini korumuştur. Bebā şekli ise alıntı kelimelerde kelime içinde bulunan /h/ sesinin düşmesi ile ortaya çıkan uzunluk sonucunda baa şeklini almıştır.

Şabas Far: cesur, babayiğit (Yudahin, 1985b, s. 395)< şāh-bāz: 2. yiğit, şanll, gösterişli (adam) (Devellioğlu, 2008, s. 975).

Kırgız Türkçesinde Farsçadan girmiş olan kelimelerde kelime içinde yer alan /h/ sesi düşer ve yanındaki ünlüleri uzatır. Bu kurala göre şāh kelimesi Kırgız Türkçesinde şaa "2. Güç, kuvvet, kudret" (Arıkoğlu vd., 2017: 1881) şeklini almıştır. Kırgız Türkçesinde kelime sonunda -z>-s değişmesi sadece $\mathrm{mAz}$ olumsuz geniş zaman ekinde -BAs/-BOs şeklinde görülürken (Kasapoğlu, 2005, s.89) bu değişme şāh-bāz > şabas kelimesinde de görülmektedir.

Tarbaza Far: darbaza ile aynı anlamdadır: kap1, avlu kapısı (Yudahin, 1985b, s. 208)< dervāze: kap1, kale kapısı, şehir kapısı (Devellioğlu, 2008, s. 177).

Arapça ve Farsça kelimelerde yazılmayan ünlü Kırgız Türkçesinde büyük çoğunlukla /a/ olarak kullanılmaktadır (Kasapoğlu, 2005, s. 74). Aynı zamanda Farsça kelimelerde sonda yer alan ve /h/ ile yazılan /e/ ünlüsü de Kırgız Türkçesinde kalınlaşarak /a/ şeklini almıştır (Kasapoğlu, 2005, s. 75). Günümüzde ise Farsça dervāze kelimesinden gelişmiş darbaz̧a (Arıkoğlu vd., 2017, s. 785) şekli kullanılırken kelime başındaki /d/ sesinin tonlulaşarak /t/ şeklini almış olan tarbaz̧a şekline rastlanmamaktadır.

Yaki Far: veya, ya da: yoksa (Yudahin, 1985b, s. 474). Kelime, Farsça yā "o halde, öyle ise" (Devellioğlu, 2008, s. 1345) anlamında kullanılan edata bir ismi veya bir cümleyi arkadan gelen cümleye bağlamak için kullanılan Farsça ki (Devellioğlu, 2008, s. 597) edatının birleşiminden oluşmuştur. 
Tablo 1. Sözlïkte Geçen Farş̧a Kelimeler

\begin{tabular}{|c|c|c|c|}
\hline Kırgızca-Rusça Sözlük & Kırgız Tilinin Sözdügü & Kırg1zca-Türkçe Sözlük & Kırg1z Ağılalar Sözlüğü \\
\hline Abaz & + & + & $+($ avaz $)$ \\
\hline Amma, amme & + & + & + \\
\hline Aram & + & + & - \\
\hline Ariyne & + & + & + \\
\hline Azbaray & - & - & + (azbäräy) \\
\hline Barañda & + & + & - \\
\hline Berende & - & + & - \\
\hline Berk & - (barik) & - & + (bärk) \\
\hline Butparas & + & + & + (putpäräz) \\
\hline Cahan & + & + & + \\
\hline Caran & - & - & - \\
\hline Darçin & - & + & - \\
\hline Daramet & + & + (daremet) & + (därämät) \\
\hline Dastar & + & + & - \\
\hline Faana & - & - & - \\
\hline Irooşan & - & - & - \\
\hline Kerkana & + & + & + (kärkänä) \\
\hline Koco & + & + & + \\
\hline Külüstön & + & + & + (gülistän) \\
\hline Lep & - & - & + \\
\hline Mader & - & + & - \\
\hline Meymankana & + & + & - \\
\hline Nar & - & - & - \\
\hline Niyaz & + & + & - \\
\hline Orozgar & + & + (orozger) & + (orozger) \\
\hline Paya & - & - & + \\
\hline Perberdiger & - & - & - \\
\hline Sarbar & + & + & + (särvär) \\
\hline Serbaa & + & - & + \\
\hline Şabas & + & + (şaabaz) & - \\
\hline Tarbaza & - & - & - \\
\hline Yaki & + & - & + (yäki) \\
\hline
\end{tabular}

Yukarıda tabloda geçen Farsça kelimelerden azbaray, berk, caran, darçin, daremet, faana, ırooşan, lep, mader, nar, paya, perberdiger, tarbaza kelimelere son dönemde hazırlanmış olan Kırgız Türkçesi

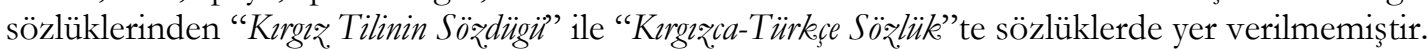

\section{Seyrek Kullanılan Arapça Kelimeler}

Alba, alva Ar:: helva (Yudahin, 1985: 46)< helvā: unlu, yağlı ve şekerli maddelerle yapılan bir tatlı (Devellioğlu, 2008, s. 354).

Alıntı kelimelerde kelime başı, kelime içi ve kelime sonunda görülen /h/ sesi Kırgız Türkçesinde genellikle düşer (Kasapoğlu, 2005, s.102). Aynı zamanda diş-dudak ünsüzü olan /v/ sesi Kırgız Türkçesinde Rusça kelimeler dişında bulunmaz. Arapça kelimelerde ise /b/'ye dönüşür (Kasapoğlu, 2005, s. 92). 226).

Arbap Ar: efendi, başkan (Yudahin, 1985a, s. 66)< erbāb: sāhipler, mālikler (Devellioğlu, 2008, s.

/b/ ünsüzü Türkçe kelimelerde sonda bulunmaz. Alıntı kelimelerin sonunda bulunan /b/ sesi Kırgız Türkçesinde /p/'ye dönüşür (Kasapoğlu, 2005, s. 55).

Asa $A r$ : 3. akraba, aile üyesi (Yudahin, 1985a, s. 74)< a'zā: organlar, üye (Devellioğlu, 2008, s. 56). Alıntı kelimelerde kelime başı ve kelime içinde yer alan $/ \varepsilon /$ işareti düşer ve uzunluk korunur (Kasapoğlu, 2005, s.50). Arapça a'zā kelimesinden gelişmiş olan asa şekline Ekrem Arıkoğlu başkanlığında hazırlanmış olan "Korgızca-Türkse Sözlüke"te yer verilmemiştir. Mukambayev ise asa şeklinin Cerge-Tallı Kırgızlar tarafindan kullanıldığını belirtmiştir (2009, s. 132).

Asıl Ar:: 2. (güney ve kuzey ağzında) ürün, mahsul (Yudahin, 1985a, s. 76)< hāsıl: husûle gelen, husûl bulan, peydā olan, çıkan, üreyen, türeyen, biten (Devellioğlu, 2008, s. 334).

Arapça kelimelerin başında, ortasında ve sonunda bulunan /h/ sesi Kırgız Türkçesinde düzenli olarak düşer. 
Ayız Ar: < aybaşı: etek kir ile aynı anlamdadır (Yudahin, 1985a, s. 36)< hayz: aybaşı (kadınlarda) (Devellioğlu, 2008, s. 349). Arapça kelimelerin başında, ortasında ve sonunda bulunan /h/ sesi Kırgız Türkçesinde düzenli olarak düşer. Aynı zamanda çift ünsüz ile biten alıntı kelimelerde bu ünsüzler arasında /1/ türer (Kasapoğlu, 2005, s. 82).

Azım Ar: büyük (Yudahin, 1985a, s. 27)< azîm: büyük, ulu, iri (Devellioğlu, 2008, s. 58).

Kırgız Türkçesinde Arapça ve Farsçadan giren kelimelerde yer alan /î/ ünlüsü kısalarak /1/'ya dönüşür (Kasapoğlu, 2005, s. 50).

Bakı Ar:: 2. ebedi (Yudahin, 1985a, s. 101)< bākî: Dāimî, kalıcı (Devellioğlu, 2008, s. 68).

Kırgız Türkçesinde Arapçadan girmiş olan kelimelerde görülen /ā/ ünlüsü çoğunlukla kısalır ve /î/ ünlüsü kısalarak /1/'ya dönüşür (Kasapoğlu, 2005, s. 50).

Buynat Ar: kurma, tesis etme: temel. Buynat bolgon kuyundan (kasirgadan olusan) (Yudahin, 1985a, s. 156). Yudahin, sözlüğünde bu kelimeyi Arapça olarak belirtmiştir. Ancak bu kelimenin Farsça bünyād "1. asıl, temel, esas 2. bina, yapı" (Dvellioğlu, 2008, s. 132) kelimesinden gelerek metatez sonucunda buynat şeklini almış olduğunu söyleyebiliriz.

Cagni Ar: yani, ne demek: başka değişle (Yudahin, 1985a, s. 210)< ya’nî: 1. Demek, şu demek. 2. Sözün kısası, doğrusu, senin anlayacağın (Devellioğlu, 2008, s. 1156).

Genel Türkçede kelime başında yer alan /y/ sesi Kırgız Türkçesinde /c/ sesine döndügünden Kırgız Türkçesinde alıntı kelimeler dışında kelime başında /y/ ünsüzü görülmez (Kasapoğlu, 2005, s. 59). Ancak incelediğimiz sözlüğe baktığımızda Rusça kelimeler ile Arapça yagni kelimesi dışında diğer Arapça kelimelerin başında yer alan /y/ sesinin Kırgız Türkçesinde /c/'ye dönüştüğünü söyleyebiliriz. Arapça kelimelerde kelime başı ve kelime içinde yer alan /ع/ Kırgız Türkçesinde genel olarak düştügü görülür ama bu örnekte /-g-/ sesine dönüştüğü görülmektedir.

Cahannam Ar: caannam ile aynıdır: cehennem (Yudahin, 1985a, s. 240)< cehennem: ahirette, günahkar kulların gideceği azap yeri, tamu (Devellioğlu, 2008, s. 130). Arapça ve Farsça kelimelerde yazılmayan /ä/ ünlüsü Kırgız Türkçesinde büyük çoğunlukla /a/'lı şeklinde kullanılmaktadır (Kasapoğlu, 2005, s. 74).

Aynı zamanda kelime içinde yer alan /h/ sesinin düşmesiyle caannam şeklini aldığ1 örneği de bulunmaktadır.

Dakıl Ar: gelen, katılan (Yudahin, 1985a, s. 182)< dāhil: iç, içeri, içinde, içeri girmiş (Devellioğlu, 2008, s. 161). Arapçadan girmiş olan kelimelerde yer alan /h/ sesi Kırgız Türkçesinde düzenli olarak art damak /k/ sesine dönüşür (Kasapoğlu, 2005, s. 91).

Dal Ar: 1. Arap alfabesinde "d" harfinin adıdır. 2. beli bükülmüş, kamburlaşmış (Yudahin, 1985a, s. 181).

EdÀ: Ar:: 1. ödeme. 2. yapma, yerine getirme 3. tavır, tarz 4. çalım (Akın, 2010, s. 698) anlamında kullanılan bu kelime Kırgız Türkçesinde ve ağızlarında "tükenmek, bitmek" anlamında ada, adak, ada- bol-, adak bol- (Yudahin, 1985a, s. 21; Mukambaev, 2009, s. 77-78; Arıkoğlu vd., 2017, s. 35) şeklinde kullanılmaktadır. Kelime Krg. $-\mathrm{k}<-\varnothing$ : alkak, alka < Ar. halķa (Akın, 2010: 487) örneğinde olduğu gibi Arapça edÀ kelimesinin sonuna /-k/ ünsüzü türemiştir.

Hak Ar: ak kelimesinin 2. anlamı ile aynıdır: gerçek, doğru (Allah'ın vasfi) (Yudahin, 1985b, s. 330)< hakk: 2. Doğruluk ve insaf (Devellioğlu, 2008, s. 314). Arapça kelimelerin başında yer alan /h/ sesi Kırgız Türkçesinde düzenli olarak düşmektedir. Aynı zamanda alıntı kelimelerde yer alan ikiz ünsüzlerin tekleşmesi olayı ise meşakkat> maşakat, kuvvet>kubat, dukkan> dükön kelimelerinde olduğu gibi iç seste görülür (Kasapoğlu, 2005, s.98). Aynı şekilde Arapça bakk kelimesinin sonunda bulunan ikiz ünsüzün de Kırgız Türkçesinde tekleştiği görülmektedir. Bu kurallara göre hakke kelimesi, Kırgız Türkçesinde yaygın olarak ak şeklinde kullanılırken incelediğimiz sözlükte nadir olarak bak şeklinin de kullanıldığı belirtilmiştir.

Hinzır Ar: domuz (Yudahin, 1985b, s. 331)< hinzîr: domuz (Devellioğlu, 2008, s. 362).

Arapça ve Farsça kelimelerde kullanılan /î/ ünlüsü kısalarak /1/'ya dönüşür. Kelime başında yer alan /hog/ sesi Kırgız Türkçesinde art damak /k/ sesine dönüşürken bu örnekte orijinal şeklini koruduğu 
görülmektedir. Kırgızların hınそ̨r yerine yaygın olarak doñu “yabani domuz" (Arıkoğlu vd., 2017, s. 828) kelimesini tercih ettikleri görülmektedir.

Ilabbay Ar: efendim, buyurun (Yudahin, 1985b, s. 429)< lebbeyk: "buyurunuz, emir sizindir efendim" manasında kullanılan bir kelime (Devellioğlu, 2008, s. 545). Kırgız Türkçesinde /1/ ve /r/ ünsüzleri ile başlayan alıntı kelimelerin başına yaygın olarak /1/ ünlüsü türetilirken yerine göre Orus, orozo, uruksat gibi kelimelerde olduğu gibi /o/ ve /u/ türetildiği görülür (Kasapoğlu, 2005, s. 80). Aynı zamanda Arapça kelimelerin yazımında gösterilmeyen /e/ ünlüsü Kırgız Türkçesinde /a/'ya dönüşür.

İrada $A r:$ irade, istem (Yudahin, 1985a, s. 302)< irāde: 1. Dileme, isteme, meram etme (Devellioğlu, 2008, s. 444). Arapça kelimelerde görülen /ā/ ünlüsü Kırgız Türkçesinde kısalarak /a/ şeklinde kullanılırken kelimelerin sonun yer alan güzel h / / dediğimiz işaret ile gösterilen /e/ sesi kalınlaşarak /a/'ya dönüşür.

Kattam Ar: dövme, toplu dayak (Yudahin, 1985a, s. 359)< katl-i āmm: zapt olunan bir yerin, irili ufaklı bütün halkını kılıçtan geçirme (Devellioğlu, 2008, s. 496).

Arapça katl-i ‘āmm kelimesinde yer alan /-1-1-/ ünlüsü Kırgız Türkçesinde alıntı kelimelerde görülen orta hecede yer alan /-1-/ ünlüsü kısalarak düşmesi kuralına göre düştüğü görülmektedir. Aynı zamanda Türkçede ünsüzler arasında ünsüz uyumunun olduğunu ve ünsüzlerin ton bakımından birbirini takip ettiklerini tonlu ünsüzlerden sonra tonlu, tonsuz ünsüzlerden sonra da tonsuz ünsüzlerin geldiğini ve bu kuralın Kırgız Türkçesinde diğer Türk lehçelerine göre ileri noktada olduğunu dikkate alacak olursak bu kelimenin katl-i āmm>katlāmm> kattam şeklinde gelişmiş olduğunu söyleyebiliriz.

Kayıda Ar: kural, kaide: Dindik kayıdalar (Dini kaideler) (Yudahin, 1985a, s. 324)< kaide: 1. Esas, temel 2. Usul, nizam, yol (Devellioğlu, 2008, s. 482). Arapça kelimelerde kelime başında ve kelime içinde yer alan / / / düşer. Fakat yanında bulunan uzun ünlülerin uzunluğu korunur. Ancak bu kelimede / $/ \varepsilon /$ işaretinin düşmeden /y/ sesine değiştiği görülmektedir. Kırgız yazı dilinde ise bu kelime kurala uygun olarak kaada "1. Örf, âdet, gelenek, anane" (Arıkoğlu vd., 2017, s. 1026) şeklinde kullanılmaktadır.

Kayrı Ar:: 1. başka, diğer, yabanc1: Kayrı şaarga kireli “yabanc şebre girelim” (Yudahin, 1985a, s. 321)< gayr: 1. Ayrı, başka, özge, artık, diğer. 2. Yabanc1, bildik olmayan (Devellioğlu, 2008, s. 280).

Alıntı kelimelerde ön seste bulunan / $\dot{g} /$ ünsüzü Kırgız Türkçesinde genellikle art damak /k/ sesine dönüşür. Aynı zamanda Arapçadan giren kelimelerde sonda çift ünsüz ve ikiz ünsüzlerin kabul edilmemesi, beraberinde kelimenin sonunda hacc $>$ ac1, hakk> akı örneklerinde olduğu gibi ünlü türemesini getirmiş̧tir (Kasapoğlu, 2005, s. 83). Bu kurala göre gayr kelimesi, $\dot{\mathrm{g}}>\mathrm{k}$ değişmesi ile /-1/ türemesinin sonucunda Kırgız Türkçesinde kayrr şeklini almıstır.

Keperet Ar: 2. ödeme, karşlltk, ödül (Yudahin, 1985a, s. 375)< keffāret: bir günaha karşı tutulmak üzere yapılan veya tutulan şey (Devellioğlu, 2008, s. 502). Alıntı kelimelerde kelime başı, kelime içi ve kelime sonunda gelen /f/ sesi Kırgız Türkçesinde /p/'ye dönüşür ve bu ses hadisesi Kırgız Türkçesinde son derece düzenlidir (Kasapoğlu, 2005, s. 91). Aynı zamanda alıntı kelimelerde iç seste bulunan ikiz ünsüzler Kırgız Türkçesinde tekleşir.

Kısas Ar:: öç, intikam (Yudahin, 1985a, s. 498)< kısās: öldüreni öldürme, yaralayanı yaralama cezası (Devellioğlu, 2008, s. 516).

Kürsü Ar: 2. taht (Yudahin, 1985a, s. 471)< kürsî: 1. Oturulacak yüksekçe yer. 2. Taht (Devellioğlu, 2008, s. 537). Alıntı kelimelerle birlikte Türkçe kelimelerde ilk hecede yer alan /ö/ ve /ü/ ünlülerinden sonra gelen /i/ ünlüleri Kırgız Türkçesinde yuvarlaklaşır. Kırgız Türkçesinde dudak uyumu diğer Türk lehçelerine göre daha güçlü ve en yüksek seviyededir. Bu nedenle Arapça ve Farsçadan giren kelimelerde de dudak uyumu etkilidir.

Labbas Ar: giysi (Yudahin, 1985b, s. 5)< libās: elbise (Devellioğlu, 2008, s. 551).

i>a değişmesi Kırgız Türkçesinde bazı alıntı kelimelerde /s/ ünsüzünün yanında siyasat>sayasat, siyahat>sayakat şeklinde görülürken Arapça libās kelimesinde ise /1/ ünsüzünden sonra görülmektedir. Aynı zamanda iç seste bulunan /b/ sesinin de ikizleştiği görülmektedir.

Lebiz Ar:: söz, ifade, anlatım (Yudahin, 1985b, s. 6)< lafz: söz (Devellioğlu, 2008, s. 539). 
Alıntı kelimelerde geçen uzun /ā/ ünlüsü Kırgız Türkçesinde çoğunlukla kısalır ve bazı yerlerde kısalarak /e/'ye dönüşür. Aynı zamanda genellikle çift ünsüzle biten alıntı kelimeler arasına kelimenin kalınlık-incelik uyumuna uygun olarak /i/ veya /1/ sesi türetilir (Kasapoğlu, 2005, s.82).

Macara Ar: başından geçenler, başa gelenler, olay (Yudahin, 1985b, s. 10) < mā-cerā: cerayan eden, geçen, olup geçen şey (bkz: ser-güzeşt) (Devellioğlu, 2008, s. 558).

Magırı Ar: batı (Yudahin, 1985b, s. 9)< magrib: 1. Garp, batı (Devellioğlu, 2008, s. 562).

Alıntı kelimelerde bulunan çift ünsüzlerin arasına Kırgız Türkçesinde kalılık-incelik uyumuna göre /i/ veya /1/ ünlüsü türetilir. /b/ ünsüzü Türkçe kelimelerin sonunda bulunmaz. Alıntı kelimelerin sonunda yer alan /b/ ünsüzü /p/'ye dönüşür(Kasapoğlu, 2005, s. 55).

Masap Ar: 1. tarikat, mezhep (Yudahin, 1985b, s. 20)< mezheb: 1. Gidilen, tutulan yol. 2. Felsefe çığırı. 3. Din. 4. Bir dinin şûbelerinden her biri (Devellioğlu, 2008, s. 640).

Arapça kelimelerin yazımında gösterilmeyen /e/ ünlüsü Kırgız Türkçesinde /a/ ile gösterilir. Aynı zamanda Arapça kelimelerin başında, ortasında ve sonunda bulunan /h/ ünsüzü de düşer ve kelime sonunda bulunan /b/ ünsüzü de /p/'ye dönüşür. Ortadaki /-z-/ sesi de tonsuzlaşarak /-s-/'ye dönmüştür.

Maşayık Ar: 2. mecazi anlamda: en iyisi (Yudahin, 1985b, s. 21)< meşāyih: şeyhler (Devellioğlu, 2008, s. 630). Arapça kelimelerin yazımında gösterilmeyen /e/ ünlüsünün Kırgız Türkçesinde /a/ ile gösterilmesi ve /ā/ ünlüsünün kısalması kuralı ile birlikte /ḩ/ ünsüzünün Kırgız Türkçesinde art damak /k/ sesine dönüşmesine uygun olarak meşāyih $>$ maşayık şeklinde gelişmiştir. Bu kelimenin anlamının Kırgız Türkçesinde genişleyerek bir işin uzmanı, ustası anlamında da kullanıldığı görülmektedir.

Maşırık Ar:: doğu (Yudahin, 1985b, s. 22) < maşrık: Güneşin doğduğu taraf, doğu (Devellioğlu, 2008, s. 585). Arapça kelimelerde iç seste kullanılan çift ünsüzlerin arasına Kırgız Türkçesinde ünlü türetilir.

Misbek Ar:: 1. misvak 2. misvak bitkisi (Yudahin, 1985b, s. 29)< misvāk: Erāk ağacının ucu dövülüp firça haline getirilen ve diş temizliğinde kullanılması sünnet olan ince dalları (Devellioğlu, 2008, s. 653). Arapçadan giren kelimelerde kelime başı ve kelime içinde yer alan /v/ sesi Kırgız Türkçesinde /b/'ye dönüşür (Kasapoğlu, 2005, s. 92).

Mugalima Ar: kadın öğretmen (Yudahin, 1985b, s. 37)< muallime: kadın öğretmen, kadın hoca (Devellioğlu, 2008, s. 658). Kırgız Türkçesinde Arapça kelimelerin başında ve içinde bulunan /ع/ düşerken bu örnekte $/ \mathrm{g} /$ 'ye dönüştügü görülmektedir. Aynı zamanda kelime içinde bulunan ikiz ünsüzler Kırgız Türkçesinde tekleşir. Kırgız yazı dilinde ise Türkçe kelimelerin cinsiyeti olmadığından kadın ve erkek öğretmen için de mugalim şekli tercih edilmiştir.

Muhit (muhut) Ar: okyanus (Yudahin, 1985b, s. 42)< muhît: 1. İhata eden, etrafını çeviren, kuşatan (Devellioğlu, 2008, s. 673).

Munaacat, munacat Ar: dua temyiz, Allah'a dua (Yudahin, 1985b, s. 38)< münācāt: 1. Allah'a dua etme, yalvarma. 2. Allah'a dua mevzulu manzume (Devellioğlu, 2008, s. 724)

O Ar:: 2. ve bağlacı (Yudahin, 1985b, s.59) < ve: dahi, de, hem, ile (Devellioğlu, 2008, s. 1141).

Sakabat Ar: cömertlik, el açıklı̆̆ı (Yudahin, 1985b, s. 124)< sahāvet: 1. cömertlik, elaçıklı̆̆1 (Devellioğlu, 2008, s. 1064). Arapça kelimelerde kelime içinde yer alan /h/ sesi düşerken bu örnekte /k/'ye dönüştügü görülmektedir. Yazılışta gösterilmeyen /e/ ünlüsü ise /a/ ile gösterilmiştir.

Aynı zamanda Arapçadan girmiş olan kelimelerde kelime içinde bulunan /-v-/ sesi Kırgız Türkçesinde /-b-/'ye dönüşür (Kasapoğlu, 2005, s. 91).

Sakıp, sakıp camal $A r$ : güzel (Yudahin, 1985b, s. 125) < sāhib-i cemāl: güzel, yakış1klı (Devellioğlu, 2008, s. 911). Arapça kelimelerde kelime içinde yer alan /h/ sesi düşerken bu örnekte /k/'ye dönüştügü görülmektedir. Aynı zamanda yazılışta gösterilmeyen /e/ ünlüsü ise /a/ ile gösterilmiştir. Kelime sonunda yer alan /b/ ünsüzü de /p/'ye döner. Aynı zamanda Arapça ve Farsça isim ve sıfat tamlamalarında kullanılan /-i/ Kırgız Türkçesinde gösterilmez.

Sana Ar: 1. y1l, kronoloji sistemi (Yudahin, 1985b, s. 132)< sene: yll (Devellioğlu, 2008, s. 937). Arapça kelimelerin yazımında gösterilmeyen /e/ ünlüsü ile kelime sonunda /o/ ile gösterilen /e/ ünlüsü Kırgız Türkçesinde /a/ ile yazılır. 
Sop 3.: 1. yalnız. 2. her şeyden yoksun kalmak (Yudahin, 1985b, s. 156). Bu kelimenin kökeni incelediğimiz sözlükte belirtilmemiştir. Ama bu kelimenin Arapça saf "1. Temiz, halis, katıksız, karışık olmayan 2. Bön, kolay aldatılabilen, kurnazlığa aklı ermeyen” (Devellioğlu, 2008, s. 1061) kelimesinden gelerek Kırgız Türkçesinde sop şeklinde kullanıldığını söyleyebiliriz.

Surapıl Ar:: (bakınız surayıl'): sadece karşllaştırma şeklinde kullanılır surapılday "surapıl gibi" (bazı kadınlar ve kuşlar için) güzel, zarif, ince, nazik (Yudahin, 1985b, s. 166).

Şaabat Ar: örtmece sperm (Yudahin, 1985b, s. 395). Arapça kelimelerde kelime içinde iki ünlü arasında bulunan /h/ sesinin erimesi ile uzunluk oluşur. Aynı zamanda kelime bașında ve kelime içinde bulunan /v/ sesi Kırgız Türkçesinde /b/'ye dönüşür. Bu kurala göre Yudahin'in sperm için örtmece olarak gösterdiği şaabat kelimesini Arapçadaki şehevāt, ssehvet, şehvāt "şehvetler, nefis düşkünlükleri, aşırı istekler” (Devellioğlu, 2008, s. 984-986) kelimesinden gelmiş olabileceğini söyleyebiliriz.

Şapaat Ar:: koruma, savunma, himaye (Yudahin, 1985b, s.402)< şefā‘at birinin suçundan geçilmesi veya dileğinin yerine getirilmesi için edilen aracılık (Devellioğlu, 2008, s. 983). Alıntı kelimelerde kelime başı, içi ve sonunda yer alan diş-dudak ünsüzü olan /f/ sesi Kırgız Türkçesinde /p/'ye döner.

Şayır Ar: 2. şair (Yudahin, 1985b, s. 397)< şā̄ir: şāir, ozan (Devellioğlu, 2008, s. 976). Arapça kelimelerde kelime başı ve kelime içinde yer alan /ع/ Kırgız Türkçesinde düşer. Bu örnekte /ع/'nın /-y/'ye dönüştüğü görülmektedir.

Şayır kelimesi günümüzde şair anlamında değil "neşeli, şen şakrak" (Arıkoğlu vd., 2017: 1895) anlaminda kullanılmaktadir.

Şımal Ar: kuzey (Yudahin, 1985b, s. 421)< şimāl: 1. Sol, sol taraf. 2. Kuzey (Devellioğlu, 2008, s. 999). Arapça ve Farsça kelimelerde iki veya daha fazla heceli olup /ā/ ünlüsü taşıyan kelimelerde ünlü benzeşmesinin sonucunda i> 1 değişmesi görülür (Kasapoğlu, 2005, s. 75).

Tilsımat (tilsim) Ar:: tılsım, büyü, büyücülük, sihirbazlık (Yudahin, 1985b, s. 237)< tılısmāt: tılsımlar (Devellioğlu, 2008, s. 1108). Kelimenin ilk hecesinde $1>$ i ses değişmesi görülmekle birlikte göçüşme görülmektedir.

Ulama Ar:: 2. ilahiyatçı, ulema (Yudahin, 1985b, s. 303)< ulemā’’ : ālimler, ilim sāhipleri (Devellioğlu, 2008, s. 1119). Arapça kelimelerin yazımında gösterilmeyen /e/ ünlüsü Kırgız Türkçesinde /a/ ile gösterilir. Aynı zamanda kelimelerde geçen hemze işareti gösterilmez.

Va Ar: ve bağlac1 (Yudahin, 1985a, s. 175)< ve: dahi, de, hem, ile (Devellioğlu, 2008, s. 1141). ve bağlacı Çağdaş Kırgız yazı dilinde kullanılmaz.

Vacip Ar: zorunlu, kaçınılmaz (Yudahin, 1985a, s. 175)< vācib: 1. Terki caiz olmayan, yapılması gerekli. 2. Yapılması şer’an lüzumlu olan, farz derecesine yakın olan (Devellioğlu, 2008, s. 1131). /b/ ünsüzü Türkçe kelimelerin sonunda bulunmadığı için alıntı kelimelerin sonunda bulunan /b/ ünsüzü Kırgız Türkçesinde /p/ olur. Uzun /ā/ da kısalır.

/v/ ünsüzü Kırgız Türkçesinde Rusça kelimeler dışında kelime başı ve kelime içinde bulunmaz ve Arapça kelimelerin başında bulunan /v/ ünsüzü /b/'ye dönüşürken bu örnekte kendisini koruduğu görülmektedir. Belki de dini terim olduğu için korunduğunu söyleyebiliriz.

Yagni Ar.: yani: ne demek (Yudahin, 1985b, s. 474)< ya'nî: 1. Demek, şu demek. 2. Sözün kısas1, doğrusu, senin anlayacağın (Devellioğlu, 2008, s. 1156). Kırgız Türkçesi kelime başı /y/ ünsüzünün yerine /c/'li şeklini korumuştur. Bu bağlamda bu kelimenin yukarıda cagni şeklinin de kullanıldığını belirtmiştik. İncelediğimiz sözlükte ikisi de nadir olmak üzere $\mathrm{y} \sim \mathrm{c}$ şeklinde ikili biçimde kullanıldığı görülmektedir.

Zayır Ar: açık, ortada, besbelli, kesin, şüphesiz (Yudahin, 1985a, s. 286)< zāhir: 2. Elbette, şüphesiz, öyledir ya (Devellioğlu, 2008, s. 1165). Alıntı kelimelerde kelime içinde yer alan /hạ/ ve /h/ sürekli ünsüzleri bazı kelimelerde /y/ sürekli ünsüzüne dönüşür (Kasapoğlu, 2005, s. 93).

Zıynat Ar:: güzellik, süsleme, bezeme (Yudahin, 1985a, s. 293)< ziynet: süs, güzelleştirme (Parlatır, 2009, s.1878)

${ }^{4}$ Yıldız kümesi, Süreyya, Ülker: "Kızdarı surayılday suluu kelet” (Kızları Ülker yıldızı gibi gibi güzeldir) (Arıkoğlu vd., 2017, s. 1864). 
Zilzala Ar: deprem (Yudahin, 1985a, s. 291)< zelzele: 2. zelzele, sarsilma, deprem (Devellioğlu, 2008, s. 1176).

Zuura Ar:: 1. Colpon ${ }^{5}$ ile aynıdır (Yudahin, 1985a, s. 292)< Zühre: Çoban yıldızı, Çulpan, Venüs (Devellioğlu, 2008, s. 1193).

Tablo 2. Sözlïkte Nadir Olarak Geşen Arapşa Kelimeler

\begin{tabular}{|c|c|c|c|}
\hline Kurgızca-Rusça Sözlük & Kırgız Tilinin Sözdügü & Kırgııca-Türkçe Sözlük & Kırg1z Ağızlar Sözlüğü \\
\hline Adak, adak bol- & + & $+(\mathrm{ada})$ & $+(\mathrm{ada})$ \\
\hline Alba, alva & + & + & - \\
\hline Arbap & + & + & $+($ arvap $)$ \\
\hline Asa & - & - & $+($ Cerge-Tal ă̆Zı $)$ \\
\hline As1l & + & + & + \\
\hline Ayız & + & + & - \\
\hline Azım & + & $+(\operatorname{azim})$ & + \\
\hline Bak1 & - & - & - \\
\hline Buynat & + & + & - \\
\hline Cagni & + & + & - \\
\hline Cahannam & + & + & - \\
\hline Dakıl & - & - & - \\
\hline Dal & - & - & + \\
\hline Hak & - & - & + \\
\hline Hinzır & - & + & - \\
\hline Ilabbay & + (1labbayka) & $+($ llabbayka $)$ & - \\
\hline İrada & + & - & - \\
\hline Kattam & - & - & - \\
\hline Kaylda & - & + & + \\
\hline Kayr1 & - & - & - \\
\hline Keperet & + & + & + (keperetip) \\
\hline Kisas & + & - & - \\
\hline Kürsü & + & + & + \\
\hline Labbas & + & + & + (livas) \\
\hline Lebiz & + & + & + (lapaz) \\
\hline Macara & + & + & - \\
\hline Magirip & - & - (magrap) & - \\
\hline Masap & - & - & - \\
\hline Maşayık & + & + & - \\
\hline Maşırıı & + & + & + \\
\hline Misbek & + & + & $+($ misbak $)$ \\
\hline Mugalima & - & - & - \\
\hline Muhit & + & + & - \\
\hline Munaacat & + & + (munacat) & - \\
\hline $\mathrm{O}$ & - & - & + \\
\hline Sakabat & + & + & + (sakavat) \\
\hline Sakıp, Sakıp camal & + & + & - \\
\hline Sana & - & - & + (sanaa) \\
\hline Sop & - & - & + \\
\hline Surap1l & - & - & - \\
\hline Saabat & - & - & - \\
\hline Sapaat & + & + & - \\
\hline Sayır & + & - & - \\
\hline Simal & + & - & - \\
\hline Tilsımat & + & + (tilsimat) & - \\
\hline Ulama & - & + & - \\
\hline $\mathrm{Va}$ & - & - & + (vä) \\
\hline Vacip & + & + & - \\
\hline Yagni & + & - & - \\
\hline Zayır & + & + & - \\
\hline Ziynat & + & - & - \\
\hline Zilzala & + & + & - \\
\hline Zuura & + & - & - \\
\hline
\end{tabular}

Sözlükte geçen Arapça kelimelerden asa, bakı, dakıl, dal, hak, hınzır, irada, kattam, kayıda, kayr1, magırıp, masap, mugalima, o, sana, sop, surapıl, şaabat, ulama, va, zuura kelimeleri son dönemde

\footnotetext{
${ }^{5}$ Venüs, Zühre (Yudahin, 1985b, s. 367).
} 
hazırlanmış olan Kırgızca sözlüklerde gösterilmemiştir. Diğer gösterilmiş olan kelimelerin de derlemelerden toplanmış olan eski metinlerde kullanmış olabileceğini söyleyebiliriz.

\section{Seyrek Kullanılan Arapça+Farsça Kelimeler}

Ayalzat Ar+Far: kadın (Yudahin, 1985a, s. 87) < 'iyāl Ar:: 2. Kadın, eş (Devellioğlu, 2008, s. 400)+ zāt (Devellioğlu, 2008, s. 1169).

Dürdana Ar. Far. 1. inci (bakınız dür) (Yudahin, 1985a, s. 204)< dürr Ar:: inci (Devellioğlu, 2008, s. 194)+ dāne Far:: 1. Tāne, tohum (Devellioğlu, 2008, s. 164).

İybadatkana $A r$ +Far: tapınak, ibadethane (Yudahin, 1985a, s. 296)< ibādet Ar: Allah'ın emirlerini yerine getirme, tapma, tapınma (Devellioğlu, 2008, s. 401)+ hāne Far: 1. Ev (Devellioğlu, 2008, s. 324). İbādet-hāne: ibadet evi, ibadet yeri, tapinak (Devellioğlu, 2008, s. 402).

\section{Seyrek Kullanılan Farsça+ Türkçe Kelimeler}

Bayla- Far.+Tür: 2. gözetlemek, izini sürmek (Yudahin, 1985a, s. 96)< pey: 2. iz, işaret (Devellioğlu, 2008, s. 863) + la (isimden fiil yapım eki) (Kasapoğlu, 2005, s. 129)> payla-ăgr takip etmek, gözetlemek (Kırgız Tilinin Sözdügü, 2011, s. 368).

Farsça kelimelerin başında bulunan /p/ ünsüzü kendini korurken bazı kelimelerde tonlulaşarak /b/’ye dönüşür.

Payla- Far.+Tür: pusuda beklemek, gözetlemek (Yudahin, 1985b, s. 106).

Bayla- filine bakınız.

Şıman-: 2. pantolonu sıvamak (Yudahin, 1985b, s. 421). Kelime şıman< şım-a-n-< şım-la-n- şeklinde gelişmiştir. Şım "pantolan” kelimesi Yudahin'in sözlüğünde Farsça olarak belirtilmiştir. Fakat Farsça sözlüklerde bu kelimeye yer verilmemiştir. - $a$ isimden fiil yapım eki<-la ekinin başındaki /1/ ünsüzünün düşmesinin sonucunda meydana gelmiştir (Oruzbaeva, 2000, s. 268). -n eki de fiilden fiil yapan dönüşlü çatı ekidir.

Kelime çağdaş Kırgız Türkçesinde şımdan- şeklinde kullanılmaktadır (Arıkoğlu vd., 2017, s. 1903).

\section{Seyrek Kullanılan Farsça+Arapça Kelimeler}

Ditkis: adam ditkis: adamdın diti ile aynı: bakını dit' (Yudahin, 1985a, s. 195). Kelime, Farsça dit "düşünce, istek, dikkat" (Yudahin, 1985a, s. 195) kelimesi ile Arapça hiss "1. duygu 2. duyu 3. sezgi, sezme” (Türkçe Sözlük, 2011, s. 1104) kelimesinin birleşiminden oluşmuştur.

\section{Seyrek Kullanılan Arapça+ Türkçe Kelimeler}

Dikattık Ar.+Tür: dikkat, özen (Yudahin, 1985a, s. 205)< dikkat $A r$ : dakiklik, incelik, ehemmiyet verme (Devellioğlu, 2008, s. 210)+-LIk/-LUk isimden isim yapım eki (Kasapoğlu, 2005, s. 115).

Kırgız Türkçesindeki kalınlık-incelik uyumuna göre ilk hecede yer alan /i/ ünlüsü uyuma uygun olarak /1/ olmuştur.

\section{Seyrek Kullanılan Farsça+Moğolca Kelimeler}

Nayzagay: çagılgan' ile aynı anlamdadır (Yudahin, 1985b, s. 51). Bu kelime, Farsça nîze "karg1, mızrak, süngü” (Devellioğlu, 2008, s. 986) kelimesi üzerine Moğolca -gay ekinin (Oruzbaeva, 2000, s. 242) getirilmesi ile oluşmuştur.

\section{Seyrek Kullanılan Rusça Kelimeler}

Peç Rus: soba (Yudahin, 1985b, s. 110).

Sud Rus.: mahkeme (Yudahin, 1985a, s. 163)< sud: mahkeme, adliye, duruşma (Rusça Büyük Sözlük, 2008, s. 817).

\footnotetext{
${ }^{6}$ Far. Arzu, istek, dikkat (Yudahin, 1985a, s. 195).

7 Şimşek, çakın, yıldırım (Taymas, 1994a, s. 244).
} 
Alıntı kelimelerde son seste bulunan /d/ Kırgız Türkçesinde tonsuzlaşarak /t/'ye dönüşür (Kasapoğlu, 2005, s. 87). Kırg1z Türkçesinde kelime içinde yer alan dar-yuvarlak olan /u/ ünlüsü genişyuvarlak /o/ ünlüsüne ve kelime sonunda kullanılan /-d/ sesinin /-t/'ye dönüşerek (Nuriahmetova, 2014, s. 340) sot şeklini almıştır. Yudahin'in sözlüğünde geçen suddal- fiili ise günümüzde sottol- şeklinde kullanılmaktadır (Arıkoğlu vd., 2017, s. 1839).

\section{Seyrek Kullanılan Rusça+ Türkçe Kelimeler}

Suddal- Rus.+Tür: mahkemeye verilmek (Yudahin, 1985a, s. 163). Kelime sud-da-l-> sot-to-lşeklinde gelişmiştir.

Yudahin'in sözlüğünde geçen suddal- fiili ise günümüzde sottol- şeklinde kullanılmaktadır (Arrkoğlu vd., 2017, s. 1839).

\section{Seyrek Kullanılan Çince Kelimeler}

Cozı. Cince. Küçük ayaklı sandalye (Yudahin, 1985a, s. 256).

Tablo 3. Sözlïkte Geçen Diğer Kelimeler

\begin{tabular}{|c|c|c|c|}
\hline Kırgızca-Rusça Sözlük & Kırgız Tilinin Sözdügü & Kırgızca-Türkçe Sözlük & Kırgız Ağılar Sözlüğü \\
\hline Ayalzat & - & - & + (Pamir Kırgızlarında) \\
\hline İybadatkana & + & + & - \\
\hline Ditkis & - & - & - \\
\hline Dürdana & + & + & - (dür şekli mevcuttur) \\
\hline Bayla- & $+($ ağız $)$ & $+($ ağız) & - \\
\hline Payla- & $+($ ağız) & $+($ ağız) & + \\
\hline Dikkattık & + & + & - \\
\hline Nayzagay & + & + & + (nadir) \\
\hline Peç & + & + & - \\
\hline Sud & $+(\operatorname{sot})$ & $+(\operatorname{sot})$ & - \\
\hline Suddal- & - & - & - \\
\hline Şıman- & - & - & - \\
\hline Coz1 & - & - & + \\
\hline
\end{tabular}

Tabloda gösterilmiş olan kelimelerden iybadatkana, dürdana, nayzagay kelimeleri son dönemde hazırlanmış olan sözlüklerde aynı şekilde gösterilmiştir. Payla- ve bayla- fiilinin ise ağızlarda kullanıldığı belirtilmiştir. Bu kelimelerden ayalzat, nayzagay ve cozı kelimeleri ise ağızlar sözlügünde geçmektedir.

\section{Seyrek Kullanılan Türkçe Kelimeler}

As (kuzey ağzında): 3. üzgün, kederli (Yudahin, 1985a, s. 74).

Baglan: kuzu (Yudahin, 1985a, s. 91).

Bakana: deve, ön ayağ1 topal olan (Yudahin, 1985a, s. 100).

Bakkıç: at baguuçu "jokey": jokey (Yudahin, 1985a, s. 100). Bak-guçı > bak-guç>bakkıç= baguuçu. Bu ek Eski Türkçede -1-gç1, -i-gçi, -guç1, -güçi şeklindeydi (Ergin, 1993, s. 181). Çağdaş Kırgız Türkçesinde uuçu,-üüçü şeklini almıştır (Kasapoğlu, 2005, s. 149). Günümüzde at bakkeıç "jokey" için yaygın olarak sayapker "koşu atlarına bakıp eğiten kimse" (Arıkoğlu vd., 2017, s. 1788) kelimesi kullanılmaktadır.

Birer: bir, aşağı yukarı (Yudahin, 1985a, s. 136).

Bul (bu, seyrek olarak bo) 1.anlamı: bu (ilgi halinde munun, yönelme halinde buga ya da boo), bo baykuş katın Ayçürök, cesir boldu muñu köp "bu zavall kadın Ayçürök, dul kald sıkemtısı çok"(Yudahin, 1985a, s. 156). Bul, işaret zamiri Isık-Köl ağzında boo şeklinde kullanılmaktadır. Aynı zamanda yönelme hali eki ile birlikte kullanıldığ1 buga "buna" şeklinin de Isık-Köl ağzında boo şeklini aldığı görülmektedir (Mukambaev, 2009, s. 244).

Ceñeçe: (nezaket şekli) hala, teyze (Yudahin, 1985a, s. 248). Çağdaş Kırgız Türkçesinde yenge için ceñe kelimesi kullanılmakla birlikte akrabalık bildiren isimlere gelerek küçültme ve sevgi ifadesi katan +ke ekinin (Kasapoğlu, 2005, s. 114) getirilmesi ile yapılmış ceñeke (Arrkoğlu vd., 2017, s. 561) şeklinin de kullanıldığ1 ve ceñeşe şeklinin kullanılmadığı görülmektedir. Oysa Yudahin, eserinde ceñeģe kelimesini hala ve teyze için seyrek olarak kullanıldığını belirtmektedir. Ceñeģe şeklinin Cergetallı Kırgızların konuşmasında genç yenge, yeni gelen genç gelin anlamında kullanıldığı görülmektedir (Mukambaev, 2009, s. 391). 
Cüzdük: yüzük, şakeke 8 ile aynı anlamda (Yudahin, 1985a, s. 273). Bu kelime "Divanü Lugat-it Lügati'tTürk"te yüzük (III.Cilt, 2018, s. 18) şeklinde geçmektedir. Eski Türkçede kelime başında bulunan /y/ ünsüzü Kırgız Türkçesinde /c/'ye dönüşmüştür (Kasapoğlu, 2005, s. 92). Bu kelimede, iç seste fazladan /d/ ünsüzünün türediği görülmektedir.

Cüzük: yüzük, șakek ile aynı anlamda (Yudahin, 1985a, s. 273).

Çap- (gerundium şekli çaap, çabıp) hızlı koşmak (Yudahin, 1985b, s. 347). Çağdaş Kırgız Türkçesinde /-p/ ile biten tek heceli fiillere, - (I)p/- (U)p zarf fiil eki getirildiğinde filin son sesi olan /-p/ önce tonlulaşarak /-b/'ye: daha sonra sızıcılaşarak /-w/'ye dönüşerek düşer (Kasapoğlu, 2005, s. 306). Çap- $+1 \mathrm{p}>$ çab-1p $>$ çaw-1p $>$ çaap şeklinde gelişir.

Çap- (gerundium şekli çaap, çabıp) kesmek, kazmak (Yudahin, 1985b, s. 347).

Eken: eken-tokon seyrek, eke-toko ile aynı anlamda (bakınız 3. ekee') (Yudahin, 1985b, s. 446).

Elbire-: epilde-10 ile aynı anlamdadır (Yudahin, 1985b, s. 447) kıvranmak: yaltaklanmak: tilkilik etmek: yaranmak

Eme: 1. ihtiyar kadın (Yudahin, 1985b, s. 452). Karahanlı Türkçesinde aba "anne" (Atalay, 2018, s. 1) anlamında kullanılan bu kelime Türkiye Türkçesinde ebe "1. doğum işini yaptıran kadın 2. halk arasında büyükanne, nine" (Türkçe Sözlük, 2011, s. 751) şeklinde kullanılmaktadır. Hakas Türkçesinde ise ebe şeklinde "babanın veya dedenin kardeşinin hanımı" anlamında kullanılmaktadır (Arıkoğlu, 2005, s. 120).

$\mathrm{Bu}$ bilgilerden yola çıkarak sözlükte geçen eme kelimesinin eme $<$ ebe $<$ aba şeklinde $\mathrm{a}>\mathrm{e}$ ve $\mathrm{b}<\mathrm{m}$ değişimine uğrayarak gelmiş olduğunu söyleyebiliriz.

Erde-: erkeklik göstermek (Yudahin, 1985b, s. 460). Bu kelime, Eski Türkçedeki er "adam, erkek" (Tekin, 2020, s. 139) kelimesine isimden fiil yapım eki olan /-de/'nin getirilmesi ile oluşmuştur. Günümüzde ise erde- fililinin yerine daha çok erdemsi- "yiğitlik taslamak, kendini yiğit sanmak" (Arıkoğlu vd., 2017, s. 890) fiili kullanılmaktadır.

Erteki: 2. Masal (Yudahin, 1985b, s. 464). Ertek kelimesi Kırgızistan'ın Leylek ilçesinde ve Özbekistan'ın Zaamin, Bökö gibi bölgelerinde yaşayan Kırgızlar tarafindan kullanılmaktadır (Mukambaev, 2009, s. 1174). Kelime, Karahanlı Türkçesinde kullanılan ert- "geçmek" (Atalay, 2018, s. 192) fiili üzerine + ak fillden isim yapım ekinin getirilmesiyle oluşmuştur.

Es-: 4. esmek (rüzgār için) (Yudahin, 1985b, s. 465). Bu fiil "Divanü Lügat'it Türk"te aynen kullanilırken (Atalay, 2018: 194) son dönemlerde hazırlanmış olan "Kırgızca-Türkşe Sözlük" ile "Kırgız. Tilinin Sözdügiü"nde gösterilmemiştir. Kelime şu anda Türkiye Türkçesinde aynı şekilde kullanılmaktadır (Türkçe Sözlük, 2011, s. 818).

Eş: 2. eş, dost (Yudahin, 1985b, s. 470). Karahanlı Türkçesinde eş (Atalay, 2018, s. 197) şeklinde kullanılan bu kelime aynı anlamda "Kırg̨z̨ca-Türkşe Söz̧lüke”te de gösterilmiștir (2017, s. 903). Ancak eş, arkadaş için yaygın olarak Farsçadan girmiş olan dost kelimesinin Kırgız Türkçesinde Farsçadan giren kelimelerde /s/ ünsüzünden sonra gelen /t/ ünsüzünün telaffuz zorluğundan düşmesi (Kasapoğlu, 2005, s. 102) kuralına göre oluşan dos şekli kullanılmaktadır.

Eşit-: (kuzey ve güney ağz1) duymak, dinlemek (Yudahin, 1985b, s. 471). Eski Uygur Türkçesinde éşit- "işitmek" (Caferoğlu, 1968, s.77), "Divanü Lügat-it Türk"te éşit- "işitmek" (Atalay, 2018, s. 198) anlamında kullanılan bu fiil eşit-şeklinde "Kırgız̨a-Türkşe Sözllük"te (2018, s. 904) aynı anlamda gösterilse de Mukambayev bu kelimenin Cerge-Tal, Batken, Leylek, Pamir bölgelerinde yaşayan Kırgızların ağzında kullanıldığını belirtmektedir (2009, s. 1178).

Kırgız yazı dilinde ise daha çok aynı anlama gelen $u k-$ (Arnkoğlu vd., 2017, s. 2154) fiilinin kullanıldığını söyleyebiliriz.

İygi: iyi, iyilik (Yudahin, 1985a, s. 296). Eski Türkçede edgü “iyi, iyilik” (Tekin, 2020, s. 137), Karahanlı Türkçesinde edhgü şeklinde (Atalay, 2018, s. 168) kullanılırken Çağatay Türkçesinde kelime içi ve kelime

\footnotetext{
8 Yüzük (Yudahin, 1985b, s. 398).

${ }^{9}$ (Yaşlı kadınlar için) deneyimli, tecrübeli (Yudahin, 1985b, s. 445).

${ }^{10}$ Becerikli ve kibar olmak, iyiliksever olmak (Yudahin, 1985b, s. 458).
} 
sonunda yer alan /dh/ sesi /y/'ye dönüşmüştür (Eckmann, 1988, s. 25). İggilik "başarı" kelimesi de ijgi kelimesinden türemiştir (Abdiev, 2020, s. 43).

Kaş: 2. değerli taş (Yudahin, 1985a, s. 362). Eski Uygur Türkçesinde kaş “3. Kaş, değerli taş, süs taşı" şeklinde kullanılmıştır (Caferoğlu, 1968, s. 170).

Kelesi: gelecek, önümüzdeki, ilerideki (Yudahin, 1985a, s. 370). Eski Anadolu Türkçesinde gelecek zaman ifade eden -as1/-esi sıfat-fill eki Karahanlı Türkçesinde de görülmektedir (Hacıeminoğlu, 2019, s. 171).

"Kırgı̨ca-Türkçe Sözlülk"te kel- filine -as1/-esi sıfat-fiil ekinin getirilmesi ile yapilmış kelesi "bir sonraki”" (2017, s. 1187) şekli ile -ar/-er sıfat-fiil ekinin getirilmesi ile yapılmış olan kelerki "bir sonraki" (2017, s. 1186) şekilleri gösterilmişse de yazı dilinde kelerki şekli kullanılmaktadır.

Kep- (gerundium keep): 4. biraz kurumak (Yudahin, 1985a, s. 375). Mahmut Kaşgarlı bu kelimeyi Kırgız ve Doğu Türkçesi lehçelerinde kep- "kurumak", Kazan ve Tobol lehçelerinde ise kip- "kurumak" (Atalay, 2018, s. 302) şeklinde kullanıldığını belirtmektedir. Ancak son dönemlerde hazırlanmış olan "Kırgız. Tilinin Sözdï̈üünde ve "Kırgızca-Türkse Sözlük"te gösterilmemiştir. Kelime şu anda kep- "kurumak" anlamında Kazak Türkçesinde kullanılmaktadır (Kazak Edebi Tilinin Sözdügü, 2007, s. 625).

Koçkor agit-: koçkor sal- seyrek olarak (Yudahin, 1985b, s. 125). Kırgızlarda koçları sürüye salarken yaygın olarak kockor sal- fili kullanılırken Yudahin, agıt- "1. bağlı hayvanı salıvermek 2. köpek, tazı ve alıcı kuşlarla avlanmak 3. aygırı sürüye katmak" fiilinin de seyrek olarak kullanıldığını belirtmiştir.

Köçküz: köcttür-11 ile aynı anlamdadır (Yudahin, 1985a, s. 433). Kelime, köş- "göç etmek" fiiline fiilden fiil yapım eki olan /-küz-/ ekinin getirilmesiyle oluşmuştur. Ettirgenlik eki olan -kIz- eki aynı görevde kullanılan -DIr- ekinin alomorfudur. Bu ek şu anda Kırgız Türkçesinde $-\mathrm{K}_{2} \mathrm{I}_{4 \mathrm{z}}$ şeklinde fiilden fiil yapımında fazla işlek olmayan şekilde kullanılmaktadır (Kasapoğlu, 2005, s. 157).

Körü: 2. körö̈12 ile aynı anlamdadır (Yudahin, 1985a, s. 430). Kırgız Türkçesinde düzlük- yuvarlaklık uyumuna göre ilk hecede yer alan /ö/ ünlüsünü sonraki hecelerde /ö/ veya /ü/ ünlüleri takip etmektedir. Buna göre Kırgız Türkçesinde -dan körö şeklinde kullanılan edatın konuşmada körü şeklinde de kullanıldığını söyleyebiliriz.

Kukulda-: 2. (kuğular için) yumurtalamak (Yudahin, 1985a, s. 439). Kukulda- $<$ kuk taklidi kelimesi üzerine -llda isimden fiil yapım ekinin getirilmesi ile yapılmıştır (Oruzbaeva, 2000, s. 103).

Kurt: 2. kurut'13 ile aynı anlamda (Yudahin, 1985a, s. 450). "Divanü Lügat'it Türk"te kurut şeklinde gösterilen bu kelimenin (Atalay, 2018, s. 386) diğer Kırgız sözlüklerinde kurt şekline rastlanmamaktadır. Kurut kelimesinin kurt şekline Kazak Türkçesinde karşılaşmaktayız (Kazak Edebi Tilinin Sözdigi, 2009, s. 420).

Mañ-: 4. (kuzey ağzında) gitmek (Yudahin, 1985b, s. 17). Eski Uygur Türkçesinde mang- "adım adım yürümek, adım, gidiş" (Caferoğlu, 1968, a. 127) şeklinde kullanılmıştır.

Mıyık: bıyık (Yudahin, 1985b, s. 46). Karahanlı Türkçesinde bıdbık şeklinde kullanılmıştır (Atalay, 2018, s. 89). Çağatay Türkçesinde kelime içi ve kelime sonunda yer alan /dh/ sesi /y/'ye dönüşmüştür (Eckmann, 1988, s. 25). Kırgız Türkçesinde Eski Türkçede kelime başındaki /b/ ünsüzü genellikle korunurken bazı kelimelerde /m/'ye dönüştüğü görülmektedir.

Bıdhık> bıyık> mıyık şeklinde gelişmiş olan bu kelime Kırgız Türkçesinde sadece mıyıgınan kül-: mingzinan cılmay-" "bıyık altından gülmek" (Kırgız Tilinin Frazeologiyalık Sözdügü, 2015, s. 562) deyiminde geçmektedir. Mıyık yerine daha çok murut "biyık" (Arıkoğlu vd., 2017, s. 1582) ile halk ağzında moyloo "bıyık" (Arıkoğlu vd., 2017, s. 1567) şekli kullanılmaktadır.

Neme: 2. kim (Yudahin, 1985b, s. 56). Neme kelimesi, ne "ne, şey" kelimesi üzerine -me enklitik ekinin getirilmesi ile oluşmaktadır. Kırgız Türkçesinde neme/eme şeklinde kullanılmaktadır (Clauson, 1972, s. 777). Yudahin, neme kelimesini "ne" anlamının yanında seyrek olarak "kim" anlamında kullanıldığını belirtmiştir.

\footnotetext{
11 Göçürtmek, taşıtmak (Yudahin, 1985a, s. 433).

12 1. Çıkma halindeki isimlerden sonra gelerek göre, nazaran anlamlarını bildirir (Arıkoğlu vd., 2017, s. 1375).

13 1. Suyu sıkılmış ve kurutulmuş kesmikten yapılan kürecikler, kurut (Taymas, 1994, s. 526).
} 
Otok: 2. otoo ${ }^{14}$ ile aynı anlamdadır (Yudahin, 1985b, s. 84). "Divanü Lúgat-it Türk"te otok kelimesi otag̉ka öpkelep süge söZlemedülk "otağa(çadırdaki) askerlere kızıp konuşmadı" cümlesinde otă̆ şeklinde kullanıldığ1 görülmektedir (III. Cilt, 2018, s. 208). Çağdaş Kırgız Türkçesinde iki heceli kelimelerde ilk ve ikinci hecelerin sonunda yer alan /g/ ünsüzünün /w/'ye dönüşerek erimesiyle uzunluk oluşur (Kasapoğlu, 2005, s. 47). Bu kurala uygun olarak otag $>$ otav $>$ otaw $>$ otoo şeklinde gelişerek günümüzde otoo "1. çobanların yaylaya giderken götürdükleri küçük keçe çadır 2. yeni gelin için kurulan küçük çadır” şeklinde kullanılmaktadır (Arıkoğlu vd., 2017, s. 1674).

Öksüz: yetim, öksüz (Yudahin, 1985b, s. 90). Anası veya hem anası hem babası ölmüş olan çocuk (Türkçe Sözlük, 2011, s. 1842). Ög, ök: anne anlamında Eski Türkçede kullanılmaktadır (Orkun, 1987, s. 826). Ög+süz> öksüz: anası veya hem anası hem babası ölmüş olan çocuk (Türkçe Sözlük, 2011, s. 1842) anlamında günümüzde Türkiye Türkçesinde kullanılmaktadır.

Sayaz: tayız ${ }^{15}$ ile aynı anlamdadır (Yudahin, 1985b, s. 139). Bu kelimesi Eski Uygur Türkçesinde say "kır, çöl, taşlık, bozkır" (Caferoğlu, 1968, s. 199) şeklinde kullanılmıştır. "Divanü Lûgat-it Türke"te de say şeklinde "kara taşılı yer" anlamında kullanılmışken aynı kelimenin Doğu Türkistan ağızlarında "düzlük çöl”, Kırgız ve Çağatay ağızlarında ise "uzun, dar dere içi, ırmak" anlamında kullanıldığı belirtilmiştir (Atalay, 2018, s. 500).

Clauson ise say kelimesinin asıl anlamını "taşlık çöl” şeklinde verirken aynı kelimenin "sı̆ğ, derinliği az" (1972, s. 858) anlamında kullanıldığını da belirtmiştir.

Söylöö-: süylö-16 ile aynı anlamdadır (Yudahin, 1985b, s. 160). "Divanü Lîgat-it Türk"te söwle- (Atalay, 2018, s. 534) şeklinde kullanılırken Kazak Türkçesinde (Kazak Edebi Tilinin Sözdigi, 2010, s. 304) ve Türkiye Türkçesinde de söylemek (Türkçe Sözlük, 2011, s. 2152) şeklinde kullanılmaktadır.

Tar1-: 2. (kuzey ağzında) sürmek, ekmek, ekip biçmek (Yudahin, 1985b, s. 213). Bu fiil Eski Uygur Türkçesinde tar1- "serpiştirmek, ekmek, tarlay1 işlemek" (Hamilton, 1998, s. 215) ve "Divanü Lûgat'it

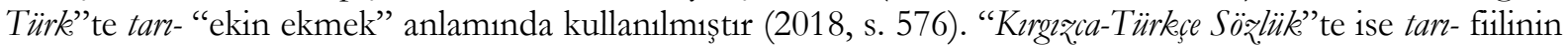
"ekin ekmek" anlamina yer verilmemiştir.

Töbö: 1. döbö̈17 ile aynı anlamdadır (Yudahin, 1985b, s. 256). Eski Türkçede töpü “tepe, doruk, zirve” (Tekin, 2020, s. 177) şeklinde kullanılmıstır. Eski Türkçede kelime başında yer alan /t/ ünsüzü Kırgız Türkçesinde genellikle korunurken teñiz $>$ deñiz, tabış $>$ dabış, toñuz $>$ doñuz gibi örneklerde $t->d-$ değişimi görülmektedir. Buna göre Eski Türkçedeki töpü kelimesi Kırgız Türkçesinde töpü> töpö döpö> töbö döbö şeklinde gelişmiştir.

Uçukta-: 3. sorgulayarak öğrenmek (Yudahin, 1985b, s. 314). Kırgız yazı dilinde uçkta- filil "iğneye ip geçirmek, takmak" (Arıkoğlu vd., 2017, s. 2152) anlamında kullanılmaktadır. Kelime "2. İğneye takılan ip" anlamında olan uçuk kelimesi ile isimden fiil yapım eki olan -la ekinden oluşmaktadır.

Kırgızlar arasında iyne-cibine çeyin: iyne-cibine deyre: iyne-cibinen beri "en küçük detaylarına kadar, eksiksiz" anlamında deyimler mevcuttur (Kırgız Tilinin Frazeologiyalık Sözdügü, 2015, s. 305). Uçukta- filinin de "sorgulayarak öğrenme" anlamı bu deyimlerle ilişkili olabileceğini söyleyebiliriz.

Ülöş: ülüss 1.18 ile aynı anlamdadır (Yudahin, 1985b, s. 322). Karahanlı Türkçesinde ülïss, ülüg, ülük "pay, halk arasında taksim, hisse" anlamında kullanılmıştır (Atalay, 2018: 712). Kırgız Türkçesinde de aynı anlamda ülüşs şeklinin korunduğu görülmek ile birlikte ülö- "bölüştürmek, bölmek, üleştirmek" fiilinden türemiş ülöss şeklinin de kullanıldığını görmekteyiz (Arrkoğlu vd., 2017, s. 2181-2182).

Üylö-: 3. (güney ve kuzey ağzında) evlendirmek (Yudahin, 1985b, s. 319). Kelime Kırgız yazı dilinde de aynı şekilde kullanıldığı görülürken Mukambayev, bu kelimenin özellikle Cerge-Tal, Pamir, Çatkal, Leylek, Özgön gibi bölgelerde yaşayan Kırgızlar arasında "evlendirmek" anlamında kullanıldığını belirtmiştir (2009, s. 980).

\footnotetext{
14 2. Yaylağa aldıkları küçük, sefer obası (Taymas, 1994b: 602).

15 Sı̆̆ (derin olmayan) (Taymas, 1988: 718).

16 Söylemek (Taymas, 1994b: 674).

17 Tepe (Taymas, 1994a, s. 312).

18 Hisse, pay (Yudahin, 1985b, s. 322).
} 
Tablo 4. Sözlükte Geçen Türkçe Kelimeler

\begin{tabular}{|c|c|c|c|}
\hline Kırgızca-Rusça Sözlük & Kırgız Tilinin Sözdügü & Kırgızca-Türkçe Sözlük & Kırgız Ağızlar Sözlüğü \\
\hline As & - & - & - \\
\hline Baglan & + & + & + (bagilan) \\
\hline Bakana & - & - & - \\
\hline Bakkıç & + (baguuçu) & + (baguuçu) & - \\
\hline Birer & + & + & + (biräär) \\
\hline Bul (bo) & + & + (boo) & + \\
\hline Ceñeçe & - & - & - \\
\hline Cüzdük & + & + & + \\
\hline Cüzük & + & + (ăğ1z) & - \\
\hline Çap- (çabıp) & - & - & - \\
\hline Eken & - & - & - \\
\hline Elbire- & + & + & + (elvire-) \\
\hline Eme & - & - & - \\
\hline Erde- & - & + & - \\
\hline Erteki & + (ertegi) & + (ertegi) & $+($ ertek $)$ \\
\hline Es- & - & - & - \\
\hline Eş & + & + & - \\
\hline Eşit- & + & + & + \\
\hline İygi & + & + & - \\
\hline Kaş & + & + & - \\
\hline Kelesi & + & + & + (kelese) \\
\hline Kep- & - & - & - \\
\hline Köçküz- & - & - & - \\
\hline Körü & - & - & - \\
\hline Kukulda- & + & + & - \\
\hline Kurt & - & - & - \\
\hline Mañ- & - & + & - \\
\hline Miyık & - & + & + \\
\hline Neme & - & - & - \\
\hline Otok & - & - & + (otow) \\
\hline Öksüz & - & - & - \\
\hline Sal- (ag1t-) & - & - & - \\
\hline Sayaz & - & - & + \\
\hline Söylö- & - & - & - \\
\hline Tar1- & - & - & + \\
\hline Töbö & + & + & - \\
\hline Uçukta- & - & - & - \\
\hline Ülöş & + & - & - \\
\hline Üylö- & + & + & + \\
\hline
\end{tabular}

Tablodaki kelimelerden adak, baglan, birer, bul, cüzük, cüzdük, elbire-, erteki, eş, eşit-, iygi, kaş, kelesi, kukulda-, mañ-, mıyık, töbö, ülöş, üylö- kelimeleri son dönemde hazırlanmış olan Kırgız sözlüklerinde gösterilmiştir. Bakkıç kelimesi ise diğer sözlüklerde baguuçu şeklinde gözterilmiştir. Bu kelimeler dışındaki diğer kelimelere son dönemde hazırlanmış olan sözlüklerde yer verilmemiştir.

\section{Kökeni Tespit Edilemeyen Kelimeler}

Kie Far: ot (Yudahin, 1985b, s. 385).

Mala Far:: 3. silah (Yudahin, 1985b, s.14).

Kabarış Ar:: 1. din değiştiren, dönek (Yudahin, 1985a, s. 310).

Babañke ${ }^{19}$ : (halk ăğıında) sefih, hovarda: sefahat (Yudahin, 1985a, s. 90).

Şumkar: 3. Farsların tabiri ile (kadınlar için) fahişe (Yudahin, 1985b, s. 414). Şumkar kelime Eski Uygur Türkçesinde şunkar “atmaca, çakır kuşu” (Caferoğlu, 1968, s. 218), Çağatay Türkçesinde ise şunkar şuñkar "şahin” (Ünlü, 2013, s.1053) şeklinde kullanılmıştır. Buna "fahişe” anlamında kullanılan şumkar kelimesinin yukarıdaki "atmaca” anlamında kullanılan şumkar kelimesiyle ilgisinin olmadığını söyleyebiliriz.

Kelimenin üçüncü anlamı şumkar kelimesi Farsça şum “uğursuz, şom” (Kanar, 2010, s. 958) kelimesi ile ger "orospu, kahpe” (Kanar, 2010, s. 1080) kelimesinin birleşiminden gelmiş olabileceğini söyleyebiliriz.

\footnotetext{
19 Kırgızcadaki sefih, hovarda anlamına gelen kelime muhtemelen Rusçadaki babnik; zampara, kadıncıl, kadın düşkünü (Rusça Büyük Sözlük, 2008, s. 30) kelimesinden gelmiş olabilir.
} 
Noyo-: noyu-20 ile aynı anlamdadır (Yudahin, 1985b, s. 57). Kırgız Türkçesinde düzlük-yuvarlaklık uyumuna göre ilk hecede yer alan /o/ ünlüsünü /o/ veya /u/ ünlüsü takip eder. Yazı dilinde noyu- şekli tercih edilmekle birlikte konuşmada noyo- şeklinin de kullanıldığını söyleyebiliriz. Kelime Moğolca < noirsa/noirsu- "dinlenmek, yatmak, uyumak" (Lessing, 1960, s. 589) filinden gelmiş olabilir.

Öm: aşırı bol, sayısız (Yudahin, 1985b, s. 94). Moğolca öng "verimli, zengin” (Lessing, 1960, s. 637) anlamında kullanılmaktadır. Buna göre öng> öm şeklinde gelişmiş olduğunu söyleyebiliriz.

Çamda-: 1. Adım atmak, yürümek (Yudahin, 1985b, s. 344). Bu kelime Moğolcada simda-/şamdah"hızlanmak, çabuk olmak, acele etmek" (Lessing, 1960, s. 709) anlamında kullanılmaktadır. Kelime şamdah> şamda->çamda- şeklinde gelişmiş olabilir. Çünkü Kırgız Türkçesinde bunun dışında aynı kökten gelen şamdagay >şamdah-gay "hareketlerinde hızlı, süratlilik, çeviklik, hareketlilik" (Arıkoğlu vd., 2017, s. 1888) kelimesi kullanılmaktadır.

Çuuda: 2. devenin dizi ile boynunun altındaki uzun yün, seyrek olarak koyunyünü için kullanilır (Yudahin, 1985b, s. 378). Clauson, yoğdu "devenin dizi ile boynunun altındaki uzun yün" kelimesinin Moğolca coğdor kelimesinden gelmiş olabileceğini söylemekle birlikte Tuvan grubunda çoğdur, Eski Kırgızcada joğdor ve Karahanlı Türkçesinde yoğdu şeklinde kullanıldığını belirtmiştir (1972, s. 899).

Kelime "Kırgızca-Türkçe Sözlük"te cogdor "1. devenin boynundaki uzun yün 1. yırtıc1 hayvanların sırt bölgesindeki, kanatlı hayvanların ise boğaz bölgesindeki tüy" (Arıkoğlu vd., 2017, s. 612) şeklinde geçmektedir. Kelime Kazak Türkçesinde şuvda "1. Ot 2. Devenin hörgücünde, sırtında ve boyun altında bulunan yün" (Kazak Sözdigi, 2013, s. 1422) şeklinde kullanılmaktadır. Buna göre kelime, kelime içinde yer alan -oğ- sesinin >-aw->-uv->-uu- gelişimi ve kelime başındaki c->ş->ç- değişiminin sonucunda çuuda haline gelmiş olduğunu söyleyebiliriz.

Köröşön: körösön²1 ile aynı anlamdadır (Yudahin, 1985a, s. 429).

Mamalak: 1. (güney ağzında) yakın yavrusu (Yudahin, 1985b, s. 15). Yudahin bu kelimenin aynı zamanda Kırgızistan'ın kuzey ağzında ayı yavrusu için de kullanıldığını belirtmiştir.

Okşokto-: okşoñdo-22 ile aynı anlamdadır (Yudahin, 1985b, s. 66).

Tipti: olumsuz anlamda takır23 ile aynı anlamda kullanılır (Yudahin, 1985b, s. 238). Kırgız Türkçesi üzerinde hazırlanmış olan "Kırgı̨ca-Türkşe Sǫ̈lük”"e baktığımızda böyle bir kullanıma yer verilmemiştir. Ancak kelimenin Tacikistan'da yer alan Cerge-Tallı Kırgızlar arasında tipti şeklinde kullanıldığ1 görülmektedir (Mukambaev, 2009, s. 904). Bu kelimenin günümüzde Kazak Türkçesinde tipti, tipten şeklinde "hepten, hiç, çok, gayet, hatta" (Koç vd., 2003, s. 575) anlamında kullanıldığı tespit edilmiştir.

Önögölüü: nümune olabilecek, örnek teşkil eden, klasik (Yudahin, 1985b, s. 95).

Tostukan: küçük boy ahşaptan yapılmış bardak (Yudahin, 1985b, s. 256). Tostukan kelimesi "Cağatay Türkçesi Sö̋liügü”nde tostugan “çanak, kadeh, testi” (Ünlü, 2013, s. 1150) şeklinde gösterilmiştir. Bu kelime Rusçaya dostokan şeklinde geçmiştir. Kırgız Türkçesinde ise bu kelime Rusçadan stkan şeklinde kısalarak geçmiştir ve orijinal şekline yakın olarak ıstakan ıstıkan şeklinde söylenir (Abdiev, 2020, s. 70).

\footnotetext{
${ }^{20}$ Yorulmak, dayanıklılığını kaybetmek, gücü azalmak (Kırgız Tilinin Sözdügü, 2010: 291).

${ }^{21}$ Azametli, haşmetli, görkemli (Yudahin, 1985a, s. 429).

22 Somurtmak, surat asmak (Taymas, 1994b: 588).

23 3. Katiyen, büsbütün (Taymas, 1994b: 699).
} 
Tablo 5. Kökeni Tespit Edilemeyen Kelimeler

\begin{tabular}{lcccc}
\hline Kırgızca-Rusça Sözlük & Kırgız Tilinin Sözdügü & Kırgızca-Türkçe Sözlük & Kırgız Ağızlar Sözlüğ̈̈ \\
\hline Kie & + & - & - \\
Mala & - & + & + \\
Kabarış & - & - & - \\
Babañke & - & - & - \\
Çamda- & + & + & - \\
Çuuda & + & + & - \\
Köröşön & - & - & - \\
Mamalak & + & + & + \\
Noyo- & - & - & - \\
Okşokto- & - & - & - \\
Öm & + & + & - \\
Önögölüü & + & + & - \\
Şumkar & - & - & + \\
Tipti & - & - & - \\
Tostukan & + & + (tostogon) \\
\hline
\end{tabular}

Tabloda gösterilmiș olan kelimelerden kie, çamda-, çuuda, mamalak, öm, önögölüü, tostukan

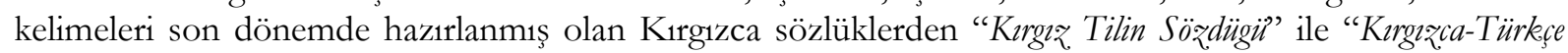
Szöllïk”te gösterilmiştir. Bunun dışında mala ve tipti kelimesi ağızlar sözlügünde aynı anlamda kullanıldığ1 görülmektedir. Geri kalan kelimelere incelediğimiz bu üç sözlükte yer verilmemiştir.

\section{Sonuç}

Sonuç olarak sözlükte Yudahin tarafindan seyrek olarak işaretlenen kelimelerin toplam sayısının 152 olduğunu tespit ettik. Tespit edilen kelimeler içerisinden kökenine ulaşabildiğimiz kelimelerin 32'si Farsça, 52' Arapça ve 40 tanesi de Türkçe kelimelerden oluşmaktadır. Bunlar dışında 3 tane Arapça ve Farsça, 3 tane Farsça ve Türkçe, 1 tane Farsça ve Arapça, 1 tane Arapça ve Türkçe, 1 tane Farsça ve Moğolca, 1 tane Rusça ve Türkçe kelimelerin birleşiminden oluşmuş kelimelerle birlikte 2 tane Rusça kelime bulunmaktadir.

Kökenine ulaşamadığımız ve kökeni şüpheli olan kelimelerden bir tanesi Çince ve diğerlerinin ise Moğolca, Türkçe ve Farsça olabileceğini düşündüğümüz toplam 16 kelime bulunmaktadır. Bunlardan sunda, çamda-, öm gibi kelimelerin Moğolcada da olduğunu dikkate alarak Moğolca olabileceği düşünülmüştür.

Sözlükte geçen Türkçe (Kırgızca) kelimelerin çoğunun çağdaş Kırgız edebî dilinde kullanılmayıp Eski Türkçede olduğu gibi ağızlarda ve diğer çağdaş Türk lehçelerinde kullanıldığı görülmektedir. Bu da yazarın bu sözlüğü hazırlamada eski edebî eserlerden, ağız araştırmacılarından faydalandığından haber vermektedir.

2011 yılında Kırgızistan Bilimler Akademisi tarafindan hazırlanan "Krrg̨ Tilinin Sözdügï" adlı sözlükte Yudahin tarafindan hazırlanan "Kırgız̨a-Rusça Söəlüke”te işaretlenen seyrek kullanılan kelimelerin 60 tanesine yer verilmemiştir. 2017 yllinda yayımlanan "Kırg̨z̨ca-Türkşe Sözlü̈k”"te ise bu kelimelerden 69 tanesine yer verilmemiştir. “Krrgız Tilinin Diyalektologiyalık Sözdügï’nde de bu kelimelerden 102 tanesine yer verilmediği görülmektedir. Abdullah Taymas'ın hazırladığ1 sözlüğün çevirisinde yukarıda geçen 152 kelimenin 37'ne yer verilmiştir.

Diğer taraftan sözlükte seyrek olarak belirtilen Arapça ve Farsça kelimelerin günümüzde Kırgız Türkçesinin ses özelliklerine göre değiştirilerek yazılış ve okunuş şeklinden uzaklaştığı, bazı cagni, yaki, va gibi edat görevinde kullanılan kelimelerin ise günümüzde yerine farklı kelimelerin tercih edilmesinden dolayı kullanımdan düşmüş olduğu görülmektedir.

\section{Etik Beyan}

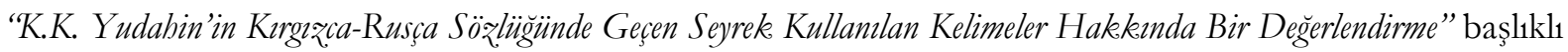
çalışmanın yazım sürecinde bilimsel kurallara, etik ve alıntı kurallarına uyulmuş; toplanan veriler üzerinde herhangi bir tahrifat yapılmamış ve bu çalışma herhangi başka bir akademik yayın ortamına değerlendirme için gönderilmemiştir. Bu araştırma doküman incelemesine dayalı olarak yapıldığından etik kurul kararı zorunluluğu bulunmamaktadır. 


\section{Kaynakça}

Abdiev, T. (2020). Söz başat (etimologiyalık etyuddar). Bişkek.

Akdoğan, Y. (1999). Az̨erbaycan Türksesin'den Türkiye Türkgesi’ne büyük sözlük. İstanbul: Beşir Yayınevi.

Akın, C. (2010). Hüseyin Karasayev'in "Kamus nama” adl eseri ve çağdas Kirgız Türkesesindeki alıntı kelimelerde görülen ses değismeleri (Doktora Tezi). İzmir: Ege Üniversitesi Sosyal Bilimler Enstitüsü.

Arıkoğlu, E. (2005). Örnekli Hakasça-Türkęe sözlükk. Ankara: AKÇAĞ Yayınları.

Arıkoğlu, E. vd. (2017). Kırgı̨̧ca-Türkese sö̊lük. Bişkek: Kırgızistan-Türkiye Manas Üniversitesi Yayınları.

Atalay, B. (2018). Divanü lûgat-it Türk diæin ve çeviri. Ankara: Türk Dil Kurumu Yayınları.

Caferoğlu, A. (1968). Eski Uygur Türkçesi sözlï̈̆̈̈. İstanbul: Edebiyat Fakültesi Matbaası.

Clauson, S.G. (1972). An etimological dictionary of pre-thirteenth-century turkish. Oxford At The Clarendon Press.

Devellioğlu, F. (2008). Osmanlica-Türkese ansiklopedik lügat. Ankara: Aydın Kitabevi Yayınları.

Eckmann, J. (1988). Că̆atayca el kitabr. İstanbul: Edebiyat Fakültesi Basımevi.

Eren, H. (1998). Türklïk bilimi sözlü̈̆̈̈, I. yabancı Türkologlar. Ankara: Türk Dili Kurumu Yayını.

Ergin, M. (1993). Türk dil bilgisi. İstanbul: Bayrak Basımı.

Hacıeminoğlu, N. (1992). Türk dilinde edatlar. İstanbul: Milli Eğitim Basımevi.

Hamilton, J.R. (1998). İyi ve kötü prens öyküsü (Çev: Vedat Köken). Ankara: Türk Dil Kurumu Yayınları.

Kanar, M. (2010). Farsça Türkşe sözlïk. İstanbul: SAY Yayınları.

Kasapoğlu Çengel, H. (2005). Kırg̨z Türkesesi grameri ses ve şekilbilgisi. Ankara: Akçă̆ Yayınları.

Kaqak edebi tiliniñ sözdigi Cilt. 10. (2009). Almatı: Tiltanım.

Kazak edebi tiliniñ sözdigi Cilt. 13. (2010). Almatı: Tiltanım.

Kazak edebi tiliniñ sözdigi Cilt. 7. (2007). Almatı: Tiltanım.

Kazake sözdigi (2013). Almat1.

Kırg̨ tilinin fraz̨eologiyalık sǫ̈dügü. (2015). Bişkek: Ç. Aytmatov atındag1 til cana adabiyat institutu.

Kırgız Tilinin Sözdügü Cilt. I-II. (2011). Bişkek: Avrasya Press, Bişkek.

Koç, K. ve Bayniyazov, A. (2003). Kaz̧ak Türkçesi Türkiye Türkşesi sözlü̈̆ü. Ankara: Akçă̆ Yayınları.

Mukambaev, C. (2009). Kırg̨z tilinin diyalektologiyalık sözdügü. Bişkek: Çıngız Aytmatov atındagı Til cana adabiyat institutu Girne Amerika universiteti Türk izildöö cana taanıtuu borboru.

Nuriahmetova, A. (2014). Günümüz Kırg1z Türkçesinde Rusça unsurlar. JASS, 27, 333-347.

Nuriahmetova, A. (2015). Kırgız sözlükçülüğü açısından Yudahin'in çalışmaları. The Journal of Academic Social Science Studies, 351-358.

Orkun, H. N. (1987). Eski Türk yazıtları. Ankara: Türk Dili Kurumu Yayınları.

Oruzbaeva, B.Ö. (2000). Söz kuramı. Bişkeke: "Mektep".

Parlatır, İ. (2009). Osmanl Türkeşesi sözlügü. Ankara: Yarg1 Yayınevi.

Rusça büyük sözlük. (2008). Rusça büyük sözlük. İstanbul: FONO Yayınları

Tekin, T. (2020). Orbon yažtları. Ankara: Türk Dil Kurumu Yayınları.

Taymas, A. (1988). Kergız sözlüğ̈, Cilt. 1-2. Ankara: Türk Dil Kurumu Yayınları.

Türkçe sözlük. (2011). Türkşe sö̊lük. Ankara: Türk Dili Kurumu Yayınları.

Ünlü, S. (2013). Çăgatay Türkçesi sözlüğ̈̈i. Konya: Eğitim Yayınevi.

Yudahin, K. K. (1985a). Kirgzz̧̧a-Orusça sözdük. Farunze.

Yudahin, K. K. (1985b). Kirgız̧a-Orusça sözdük. Farunze.

\section{EXTENDED ABSTRACT}

At the end of 1925, it was decided to revise the work and to publish it for the second time which named "Turkish Dialects Dictionary Experience" prepared by Radloff at the Academy of Sciences of the Soviet Union. In this editing process Yudahin also handled the Kyrgyz article that constitutes the 5th part of the work.

While reviewing this article, it came across many words and phrases whose meanings are not understood. Yudahin started to analyze the newspapers, textbooks, folklore and literary works of that period one by one in order to clarify such incomprehensible words. When this could not reach the result as it wanted with the resources he applied, he traveled to every region of Kyrgyzstan and made a compilation. The author mentioned that he went to Isik-Kol for compilation in 1928. Based on this information, we can say that the author was involved in compilation from 1928 to 1940 in order to prepare the work. The information he had recorded as a result of this compilation was more than the work which Radloff prepared. It was enabled for Yudahin to prepare him separate dictionary.

Since 1923, with the formation of the Kyrgyz literary language, written works in Kyrgyz Turkish have not yet reflected the richness of Kyrgyz Turkish. Therefore, Yudahin had to resort to folklore and spoken language besides literature in order to collect material. Fort the reason that Kyrgyz dictionary material was collected for the first time, Yudahin utilized all of the words in the dictionary, which he prepared in two 
volumes. During the collection of words in the dictionary, he also benefited from the leading dialect researchers and Turcologists.

In this article it was also emphasized the words marked sparse by Yudahin in the dictionary which published in 1985. In the explanation section of the dictionary, the author marked some words as rarely used words by saying redko (infrequent) in the 29th item of the 31-item of explanation. However, the author does not explain why he refers to these words as infrequently used words in the dictionary. The objective of the article is to clarify the rarely used phrase of Yudahin, to bring together these rarely used words, to reveal the original forms of the words and to determine whether they are used in other Kyrgyz dictionaries.

As a result, we found that the total number of words which marked infrequently were 154 in the dictionary. Thirty-three of the detected words are in Persian, fifty-two in Arabic and fifty-nine in Turkish. Apart from these, it consists of three made up words in Arabic and Persian, two in Persian and Turkish, one in Arabic, Turkish, Russian and Turkish, and two Russian and one Chinese word.

Most of the Turkish (Kyrgyz) words in the dictionary are not used in the contemporary Kyrgyz literary language, but it was seen that they handled in dialects and other contemporary Turkish dialects, although they are operated in Old Turkish. This indicates that the author used ancient literary works and dialect researchers in preparing this dictionary. Although words such as öksüz (orphan), söyle (say)- are used in old Turkish, but these words are not used in today's Kyrgyz Turkish. While showing these words, Yudahin raise to the occasion that he also used old written texts. While there were reaching the roots of most of the Turkish words in the dictionary, the origins of some words such as öm, eme, and eken could not be found.

Sixty-six of the infrequently used words marked in the "Kyrgyz-Russian Dictionary" prepared by Yudahin were included in the dictionary named "Kyrgyz Tilinin Sözdügü" in 2011, prepared by the Kyrgyz Academy of Sciences. Sixty-nine of these words was included in the "Kyrgyz-Turkish Dictionary" which published in 2017. It is figured out that one hundred and two of these words are included in the "Dialectological Word of the Kyrgyz Fox". In the translation of the dictionary prepared by Abdullah Taymas, it was included thirty seven from hundred fifty-four words which mentioned above.

Most of the words we have examined are Arabic and Persian, and it is noteworthy that these words are adapted according to the phonetic characteristics of Kyrgyz Turkish and diverge from the original spelling and pronunciation. It is seen that some words in Arabic are marked as infrequently used words, as Kyrgyz Turkish mostly uses Persian words instead of some religious words from Arabic.

As a consequence, we can say that most of the words that Yudahin marked sparsy are met with different words in today's Kyrgyz Turkish and some of them have been removed from the newly prepared dictionaries. 